\title{
The yeast rapid tRNA decay pathway primarily monitors the structural integrity of the acceptor and T-stems of mature tRNA
}

\author{
Joseph M. Whipple, Elizabeth A. Lane, Irina Chernyakov, ${ }^{1}$ Sonia D'Silva, and Eric M. Phizicky ${ }^{2}$ \\ Department of Biochemistry and Biophysics, Center for RNA Biology, University of Rochester School of Medicine, Rochester, \\ New York 14642, USA
}

\begin{abstract}
tRNAs, like other RNAs, are subject to quality control steps during and after biosynthesis. We previously described a rapid tRNA degradation (RTD) pathway in which the 5'-3' exonucleases Rat1 and Xrn1 degrade

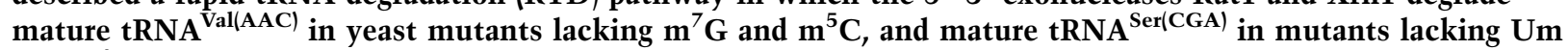
and $\mathrm{ac}^{4} \mathrm{C}$. To understand how the RTD pathway selects substrate tRNAs among different tRNAs lacking the same

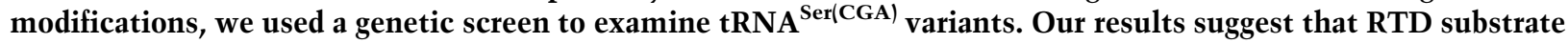
recognition in vivo depends primarily on the stability of the acceptor and T-stems, and not the anti-codon stem, and does not necessarily depend on modifications, since fully modified tRNAs are subject to RTD if appropriately destabilized. We found that weaker predicted stability of the acceptor and T-stems of tRNAs is strongly correlated with RTD sensitivity, increased RNase T2 sensitivity of this region of the tRNA in vitro, and increased exposure of the $5^{\prime}$ end to phosphatase. We also found that purified Xrn1 selectively degrades RTD substrate tRNAs in vitro under conditions in which nonsubstrates are immune. These results suggest that tRNAs have evolved not only for accurate translation, but for resistance to attack by RTD.
\end{abstract}

[Keywords: Saccharomyces cerevisiae; Xrn1; Met22; Rat1; tRNA; quality control]

Supplemental material is available for this article.

Received March 13, 2011; revised version accepted April 26, 2011.

Surveillance of RNA quality and clearance of aberrant RNAs is crucial in all studied organisms. Aberrant mRNAs are subject to nuclear surveillance and degradation, or are exported to the cytoplasm and subsequently degraded by a number of mechanisms (Doma and Parker 2007; Isken and Maquat 2007; Houseley and Tollervey 2009). Quality control pathways also recognize aberrant stable noncoding RNAs during biogenesis. A nuclear RNA surveillance pathway in yeast recognizes both pretRNAs and pre-rRNAs that are misprocessed (Kadaba et al. 2004; Kuai et al. 2004), appending a poly(A) tail to their $3^{\prime}$ ends via the TRAMP complex to trigger $3^{\prime}-5^{\prime}$ degradation by the nuclear exosome and Rrp6 (Fang et al. 2004; Kadaba et al. 2004; LaCava et al. 2005; Vanacova et al. 2005; Schneider et al. 2007). The best-characterized tRNA substrate for this nuclear RNA surveillance pathway is pre-tRNA ${ }_{i}^{\text {Met }}$ lacking 1-methyladenosine $\left(\mathrm{m}^{1} \mathrm{~A}\right)$ at posi-

${ }^{1}$ Present address: Department of Molecular Biology and Genetics, Weill Institute for Cell and Molecular Biology, Cornell University, Ithaca, NY 14853, USA.

${ }^{2}$ Corresponding author.

E-MAIL eric_phizicky@urmc.rochester.edu; FAX (585) 271-2683.

Article is online at http://www.genesdev.org/cgi/doi/10.1101/gad.2050711. tion 58 (Kadaba et al. 2006), although other pre-tRNA substrates have been identified that are misprocessed prior to splicing (Copela et al. 2008).

Stable RNAs also undergo surveillance after maturation. Mature rRNA that is defective for translation is subject to surveillance by a nonfunctional rRNA degradation pathway (NRD) (LaRiviere et al. 2006; Cole et al. 2009; Fujii et al. 2009), and mature tRNA species lacking certain modifications are subject to rapid tRNA decay (RTD) (Alexandrov et al. 2006; Chernyakov et al. 2008). Thus, mature tRNA ${ }^{\mathrm{Val}(\mathrm{AAC})}$ is rapidly deacylated and degraded at $37^{\circ} \mathrm{C}$ in a trm8- $\Delta$ trm4- $\Delta$ strain, in which tRNAs lack $\mathrm{m}^{5} \mathrm{C}$ (5-methylcytidine) and $\mathrm{m}^{7} \mathrm{G}_{46}$ (7-methylguanosine), resulting in a temperature-sensitive growth phenotype (Alexandrov et al. 2006). Similarly, mature tRNA ${ }^{\text {Ser(CGA) }}$ and tRNA ${ }^{\text {Ser(UGA) }}$ are degraded at $37^{\circ} \mathrm{C}$ in strains lacking $\mathrm{Um}_{44}$ (2'-O-methyluridine) and $\mathrm{ac}^{4} \mathrm{C}_{12}$ (4-acetylcytidine) due to lack of TRM44 and TAN1, resulting in a temperature-sensitive phenotype (Kotelawala et al. 2008).

Genetic evidence demonstrates that RTD is mediated by Met 22 and the $5^{\prime}-3^{\prime}$ exonucleases Rat 1 and Xrn1, since deletion of MET22 alone-or a combination of a RAT1 mutation and $X R N 1$ deletion-prevents the degradation of 
Whipple et al.

tRNA $^{\mathrm{Val}(\mathrm{AAC})}$ in a trm8- $\Delta$ trm4- $\Delta$ strain, restores its aminoacylation, and rescues the growth defect at $37^{\circ} \mathrm{C}$, and since deletion of MET22 prevents the degradation of tRNA $^{\text {Ser(CGA) }}$ and tRNA ${ }^{\text {Ser(UGA) }}$ in a trm44- $\Delta$ tan $1-\Delta$ strain and rescues its growth defect at $37^{\circ} \mathrm{C}$ (Chernyakov et al. 2008). Rat1 and Xrn1 are the predominant $5^{\prime}-3^{\prime}$ exonucleases in the nucleus and cytoplasm, respectively, and are presumed to be responsible for degradation, whereas Met22 is likely only indirectly involved in RTD, since its substrate, adenosine-5', $3^{\prime}$-bisphosphate, is a known inhibitor of Xrn1 and Rat1 activity in vitro (Dichtl et al. 1997).

One major question about the RTD pathway is the basis for its stringent substrate specificity. It is clear, based on prior analysis, that the missing modifications are not themselves sufficient to trigger RTD. Thus, in a trm8- $\Delta$ trm4- $\Delta$ strain, only tRNA ${ }^{\mathrm{Val}(\mathrm{AAC})}$ is degraded, whereas each of the other three tRNA species known to have $\mathrm{m}^{7} \mathrm{G}_{46}$ and $\mathrm{m}^{5} \mathrm{C}_{49}\left[\mathrm{tRNA}_{\mathrm{i}}{ }^{\mathrm{Met}}, \mathrm{tRNA}^{\mathrm{Phe}(\mathrm{GAA})}\right.$, and $\left.\mathrm{tRNA}^{\mathrm{Val}(\mathrm{CAC})}\right]$ are stable, as are tRNA ${ }^{\mathrm{Lys}(\mathrm{UUU})}, \mathrm{tRNA}^{\mathrm{Met}}$, and $\mathrm{tRNA}^{\mathrm{Cys}}$, the other tRNAs known to have $\mathrm{m}^{7} \mathrm{G}_{46}$ and $\mathrm{m}^{5} \mathrm{C}$ at other positions (Alexandrov et al. 2006; Chernyakov et al. 2008). Likewise, only tRNA ${ }^{\text {Ser(CGA) }}$ and tRNA ${ }^{\text {Ser(UGA) }}$ are degraded in a trm44- $\Delta$ tan1- $\Delta$ strain, whereas tRNA ${ }^{\text {Ser(IGA) }}$ and tRNA ${ }^{\text {Ser(GCU) }}$ are stable (Kotelawala et al. 2008), although all four tRNA ${ }^{\text {Ser }}$ species lack $\mathrm{Um}_{44}$ and $\mathrm{ac}^{4} \mathrm{C}_{12}$ in this strain (Dunin-Horkawicz et al. 2006). Thus, to understand how tRNA integrity is monitored in the cell, and how this pathway is regulated to prevent degradation of all cellular tRNAs, it is crucial to understand how the RTD pathway discriminates substrate tRNAs from nonsubstrate tRNAs.

To identify the determinants that are important for RTD in vivo, we used a simple gene replacement assay to examine individual tRNA ${ }^{\text {Ser(CGA) }}$ variants for their ability to support life. We show here that the stability of the combined acceptor and T-stems is the major element of tRNA substrate recognition by the RTD machinery, and suggest that modifications exert their effects on RTD by modulating the stability of the tertiary fold, thereby affecting the stability of the acceptor and T-stems of the tRNA. Furthermore, we provide biochemical evidence that RTD substrates have a more exposed acceptor stem, T-stem, and 5 ' end, and are preferentially degraded by purified Xrn1. These results suggest that the acceptor stem and T-stem of tRNAs have evolved in part to be stable enough to avoid attack by the major cellular 5'-3' exonucleases, in addition to the numerous other evolved structural and functional constraints of tRNA.

\section{Results}

To understand the mechanisms by which the RTD pathway discriminates substrate tRNAs from nonsubstrate tRNAs, we focused on the differential sensitivity of tRNA ${ }^{\text {Ser }}$ species to degradation by this pathway. Since all four tRNA ${ }^{\text {Ser }}$ species have both $\mathrm{ac}^{4} \mathrm{C}_{12}$ and $\mathrm{Um}_{44}$, but only tRNA ${ }^{\text {Ser(CGA) }}$ and tRNA ${ }^{\text {Ser(UGA) }}$ are degraded in trm44- $\Delta$ tan $1-\Delta$ mutants, their susceptibility to RTD must be due to some factor other than these modifications, such as sequence or structure. To evaluate these differences, we compared the RTD substrate tRNA ${ }^{\text {Ser(CGA) }}$ [which is nearly identical in sequence to tRNA $\left.{ }^{\text {Ser(UGA) }}\right]$ and the nonsubstrate tRNA $^{\text {Ser(IGA) }}$ (Fig. 1A).

There are 13 nucleotide differences between $t R N A^{\text {Ser(CGA) }}$ and tRNA ${ }^{\text {Ser(IGA) }}$, eight of which occur in the acceptor stem and T-stem-loop, which normally stack on one another to form a continuous helix. Six of these differences impact four base pairs, two of which are predicted to substantially weaken the structure of tRNA ${ }^{\mathrm{Ser}(\mathrm{CGA})}$ relative to
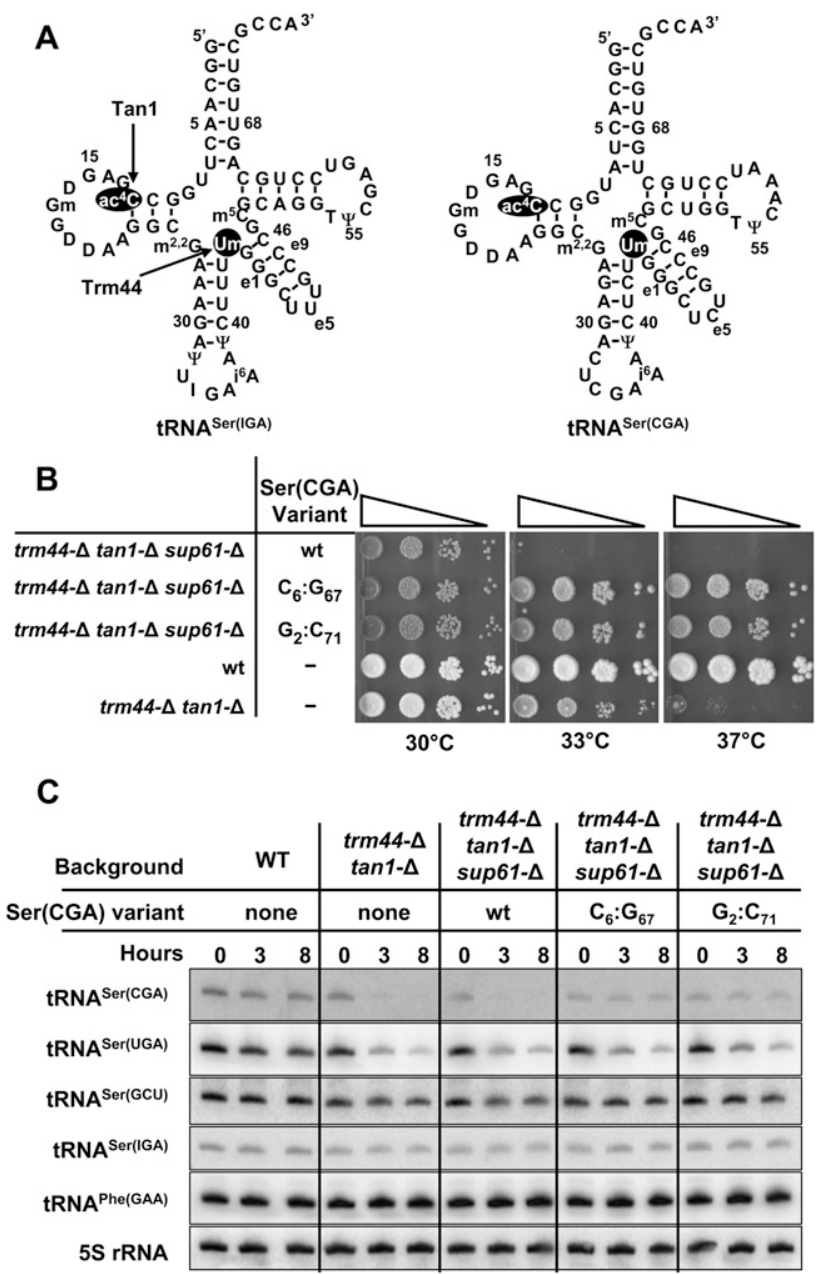

Figure 1. Substitution of G:U pairs with G:C pairs in the acceptor stem of tRNA ${ }^{\mathrm{Ser}(\mathrm{CGA})}$ restores wild-type growth to a trm44- $\Delta \tan 1-\Delta$ strain and prevents tRNA ${ }^{\text {Ser(CGA) }}$ degradation. (A) Schematic of tRNA ${ }^{\text {Ser(CGA) }}$ and tRNA ${ }^{\text {Ser(IGA) }}$ secondary structures, with $\mathrm{ac}^{4} \mathrm{C}_{12}$ and $\mathrm{Um}_{44}$ highlighted. $(B)$ Replacement of $\mathrm{G}_{2}: \mathrm{U}_{71}$ or $\mathrm{U}_{6}: \mathrm{G}_{67}$ in tRNA ${ }^{\mathrm{Ser}(\mathrm{CGA})}$ with $\mathrm{G}: \mathrm{C}$ restores growth of a trm44- $\Delta \tan 1-\Delta$ strain at $37^{\circ} \mathrm{C}$. Strains were grown overnight in YPD medium at $28^{\circ} \mathrm{C}$, adjusted to an $\mathrm{OD}_{600}$ of $\sim 0.5$, and serially diluted 10 -fold, and $2 \mu \mathrm{L}$ was spotted onto YPD and grown for $2 \mathrm{~d}$ at the indicated temperatures. Each image is derived from cells on the same plate. $(C)$ G:C-substituted tRNA $^{\text {Ser(CGA) }}$ variants are resistant to degradation in a trm44- $\Delta$ tan1- $\Delta$ strain. Strains were grown in YPD, treated with thiolutin, and shifted to $37^{\circ} \mathrm{C}$; cells from the indicated time points were harvested; and $3 \mu \mathrm{g}$ of bulk RNA was analyzed by Northern blot analysis. 
tRNA $^{\text {Ser(IGA): The } \mathrm{U}_{6}: \mathrm{G}_{67} \text { pair in tRNA }}{ }^{\mathrm{Ser}(\mathrm{CGA})}$ is $\mathrm{C}_{6}: \mathrm{G}_{67}$ in tRNA $^{\text {Ser(IGA) }}$, and the $U_{51}: U_{63}$ mismatch in tRNA ${ }^{\text {Ser(CGA) }}$ is $A_{51}: U_{63}$ in tRNA ${ }^{\text {Ser(IGA) }}$. Since the other two base pair differences are predicted to be only mildly stabilizing or neutral $\left[\mathrm{C}_{5}: \mathrm{G}_{68}\right.$ in $\mathrm{tRNA}^{\mathrm{Ser}(\mathrm{CGA})}$ vs. $\mathrm{A}_{5}: \mathrm{U}_{68}$ in $\mathrm{tRNA}^{\mathrm{Ser}(\mathrm{IGA})}$, and $A_{7}: U_{66}$ in tRNA ${ }^{\text {Ser(CGA) }}$ vs. $U_{7}: A_{66}$ in tRNA $\left.{ }^{\text {Ser(IGA) }}\right]$, the overall effect is to destabilize the structure of the combined acceptor and T-stems of tRNA ${ }^{\mathrm{Ser}(\mathrm{CGA})}$ by $4.5 \mathrm{kcal} / \mathrm{mol}$, as calculated using the RNAstructure program (Reuter and Mathews 2010). Because of the presumed importance of the $5^{\prime}$ end of tRNA for Rat1 and Xrn1 exonuclease activity, we reasoned that the weaker predicted stability of the acceptor and T-stems of tRNA ${ }^{\text {Ser(CGA) }}$ might be the reason that $\mathrm{tRNA}{ }^{\mathrm{Ser}(\mathrm{CGA})}$ is a substrate for RTD, whereas

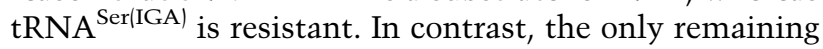
base pair difference between the two tRNAs is $\mathrm{N}_{28}: \mathrm{N}_{42}$ in the anti-codon stem, and this pair would increase, rather than decrease, the stability of the anti-codon stem of tRNA $^{\text {Ser(CGA) }}$ relative to tRNA ${ }^{\text {Ser(IGA) }}$.

To determine the contribution of structural features of tRNA to RTD substrate specificity, we constructed a sensitive genetic system to screen tRNA ${ }^{\text {Ser(CGA) }}$ variants in vivo. $\mathrm{tRNA}^{\mathrm{Ser}(\mathrm{CGA})}$ is ideal as an RTD reporter because it is the one known RTD substrate that is encoded by a single copy-essential gene, SUP61 (Etcheverry et al. 1982), and because expression of tRNA ${ }^{\text {Ser(CGA) }}$ alone substantially rescues the temperature-sensitive growth defect of a trm44- $\Delta$ tan1- $\Delta$ strain (Kotelawala et al. 2008). We therefore developed a shuffle assay in which a tRNA ${ }^{\text {Ser(CGA) }}$ variant is integrated at the ADE2 locus of a sup61- $\Delta$ [URA3 SUP61] strain and transformants are tested for growth after 5-fluoroorotic acid selection against the URA3 SUP61 plasmid (Supplemental Fig. S1).

\section{A major determinant of RTD specificity for $t R N A^{\text {Ser }}$ species is the predicted stability of the acceptor and T-stems}

We found that a number of tRNA ${ }^{\text {Ser(CGA) }}$ variants that increase the predicted stability of the acceptor and T-stems rescue the temperature sensitivity of a trm44- $\Delta$ tan1- $\Delta$ strain and prevent degradation of mature tRNA ${ }^{\mathrm{Ser}(\mathrm{CGA})}$ by the RTD pathway. Thus, substitution of $\mathrm{G}_{2}: \mathrm{U}_{71}$ by $\mathrm{G}_{2}: \mathrm{C}_{71}$ in tRNA ${ }^{\text {Ser(CGA) }}$, or of $\mathrm{U}_{6}: \mathrm{G}_{67}$ by $\mathrm{C}_{6}: \mathrm{G}_{67}$, completely restores growth of a trm $44-\Delta \tan 1-\Delta$ strain at $37^{\circ} \mathrm{C}$, whereas the same strain with wild-type tRNA ${ }^{\mathrm{Ser}(\mathrm{CGA})}$ is temperature-sensitive at $33^{\circ} \mathrm{C}$ (Fig. 1B). Furthermore, these tRNA ${ }^{\text {Ser(CGA) }}$ variants are fully stable in trm44- $\Delta \tan 1-\Delta$ strains $8 \mathrm{~h}$ after the shift to $37^{\circ} \mathrm{C}$ [although both wild-type and variant tRNA ${ }^{\text {Ser(CGA) }}$ constructs at the $A D E 2$ locus maintain lower steady-state levels of tRNA ${ }^{\text {Ser(CGA) }}$ relative to wild-type tRNA ${ }^{\text {Ser(CGA) }}$ at

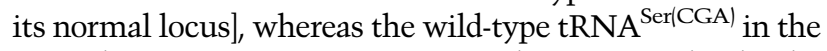
control trm44- $\Delta$ tan1- $\Delta$ strain is almost completely degraded after $3 \mathrm{~h}$ (Fig. 1C). As expected, tRNA ${ }^{\text {Ser(UGA) is }}$ degraded with the same time course in all of the trm44- $\Delta$ $\tan 1-\Delta$ strains, and tRNA ${ }^{\text {Ser(IGA) }}$ and tRNA ${ }^{\text {Ser(GCU) }}$ are stable (Fig. 1C). Similarly, each of three tRNA ${ }^{\text {Ser(CGA) }}$ variants that pair the $\mathrm{U}_{51}: \mathrm{U}_{63}$ mismatch in the T-stem (Fig. 2A) completely restores growth to a trm44- $\Delta \tan 1-\Delta$ strain and is stable after a temperature shift (Fig. 2B,C).
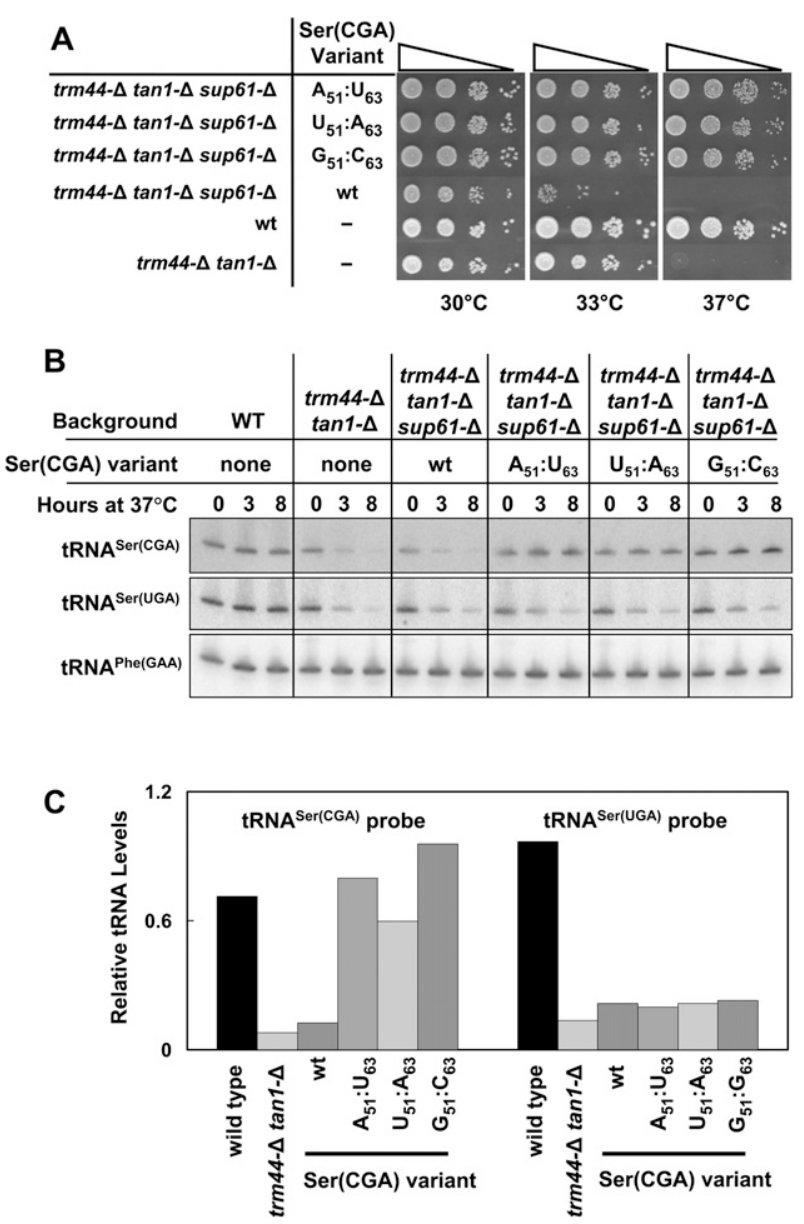

Figure 2. Substitution of the $\mathrm{U}_{51}-\mathrm{U}_{63}$ T-stem mismatch in tRNA ${ }^{\text {Ser|CGA) }}$ with a G:C or A:U pair restores growth to a trm44- $\Delta$ $\tan 1-\Delta$ strain and prevents tRNA ${ }^{\text {Ser(CGA) }}$ degradation. (A) Replacement of $U_{51}-U_{63}$ of tRNA ${ }^{\text {Ser(CGA) }}$ with G:C or A:U restores growth of a trm44- $\Delta \tan 1-\Delta$ strain at $37^{\circ} \mathrm{C}$. Strains were grown and plated as in Figure 1B. $(B)$ tRNA $^{\text {Ser(CGA) }}$ variants are resistant to degradation in a trm44- $\Delta$ tan1- $\Delta$ strain upon replacement of $\mathrm{U}_{51}-\mathrm{U}_{63}$ of $\mathrm{tRNA}{ }^{\mathrm{Ser}(\mathrm{CGA})}$ with G:C or A:U. Strains were grown and treated as described in Figure 1C, and $3 \mu \mathrm{g}$ of bulk RNA was analyzed by Northern blot. $(C)$ Quantification of tRNA ${ }^{\text {Ser(CGA) }}$ and tRNA ${ }^{\text {Ser(UGA) }}$ levels $8 \mathrm{~h}$ after temperature shift. Levels of tRNA $^{\text {Ser }}$ species were normalized to tRNA ${ }^{\text {Phe }}$ levels in the same sample, and then divided by the normalized levels of the same tRNA species in the wild-type parent strain (BY4741) prior to temperature shift.

We also found that the degree of growth rescue of a trm44- $\Delta$ tan1- $\Delta$ strain is strongly correlated with the predicted increase in stability of the acceptor and T-stems of each tRNA ${ }^{\text {Ser(CGA) }}$ variant. The healthy growth observed at $37^{\circ} \mathrm{C}$ with $\mathrm{G}_{2}: \mathrm{C}_{71}, \mathrm{C}_{6}: \mathrm{G}_{67}$, or $\mathrm{N}_{51}: \mathrm{N}^{\prime}{ }_{63}$ variants is associated with predicted stabilization of the acceptor and T-stems by 2.3-6.1 kcal/mol (Fig. 3, rows 2,4,5,7,9). Variants with more modest increases in predicted stability of these stems only restore growth at a more limited range of temperatures. Thus, replacement of $\mathrm{G}_{2}: \mathrm{U}_{71}$ by

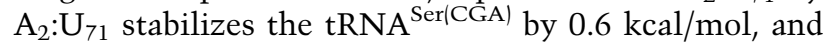
the resulting strain is healthy only up to $35^{\circ} \mathrm{C}$ (Fig. 3 , cf. 


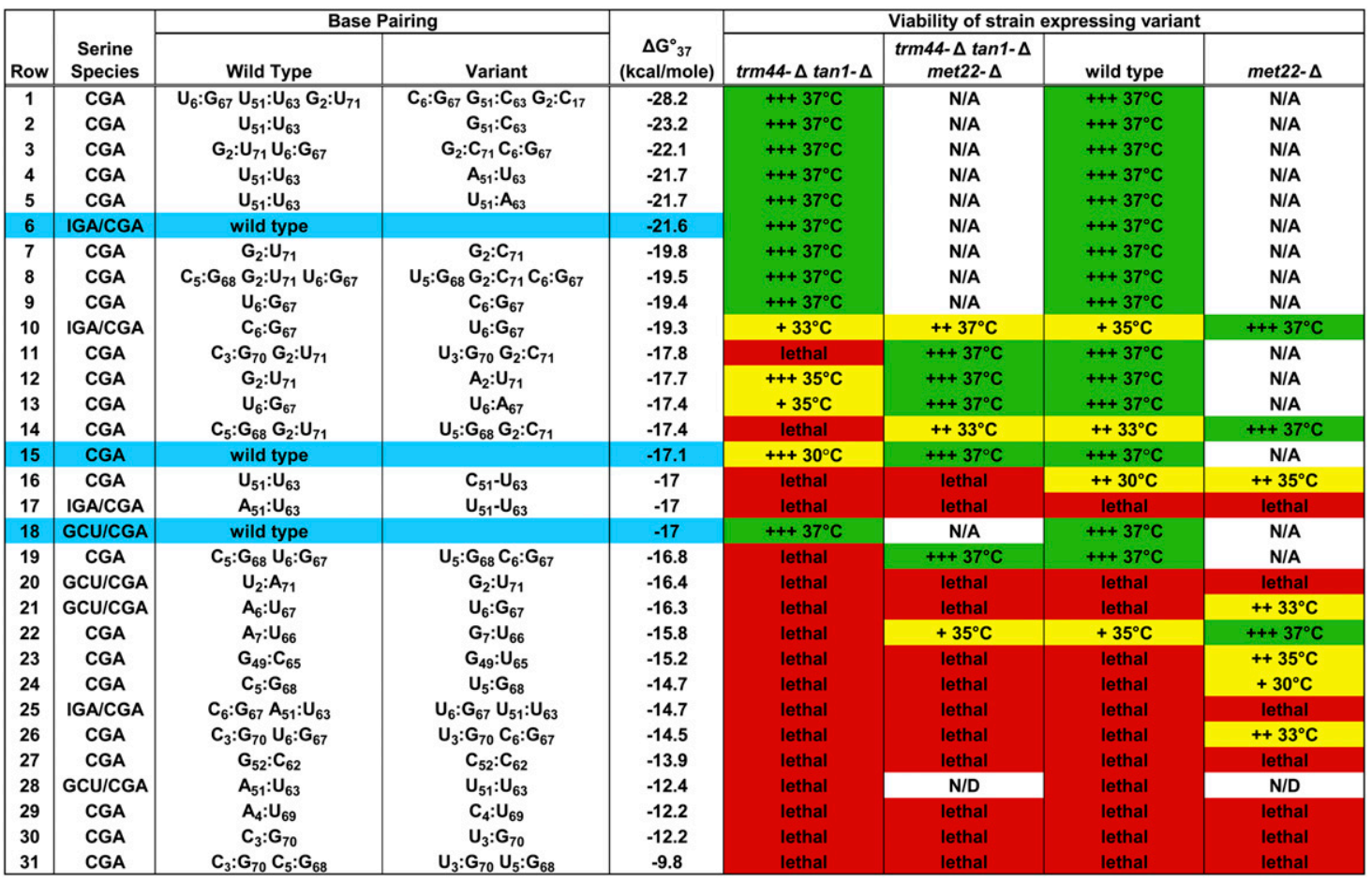

Figure 3. Analysis of tRNA ${ }^{\text {Ser }}$ variants with substitutions in the acceptor stem and T-stem. Strains with different tRNA ${ }^{\text {Ser }}$ variants were grown overnight, serially diluted, plated on $\mathrm{YPD}$, and incubated for $2-3 \mathrm{~d}$ at $25^{\circ} \mathrm{C}, 30^{\circ} \mathrm{C}, 33^{\circ} \mathrm{C}, 35^{\circ} \mathrm{C}$, and $37^{\circ} \mathrm{C}$, and growth was examined and compared with the predicted stability of the acceptor and T-stems (Reuter and Mathews 2010). The highest temperature at which growth was observed is listed, and, in each case, healthy growth is observed at the next lower temperature. For the tRNA $^{\text {Ser(CGA) }} \mathrm{C}_{51}: \mathrm{U}_{63}$ variant, growth was evaluated only by replica plating. (+++) Healthy growth; $(+)$ poor but distinct growth; (green) healthy growth at $37^{\circ} \mathrm{C}$; (yellow) intermediate growth; (red) lethal; (N/A) met22- $\Delta$ derivative strain not made, since healthy growth was observed without suppression; (N/D) strain not made.

rows 12 and 15 ); replacement of $\mathrm{U}_{6}: \mathrm{G}_{67}$ by $\mathrm{U}_{6}: \mathrm{A}_{67}$ stabilizes the tRNA by $0.3 \mathrm{kcal} / \mathrm{mol}$, and supports growth only weakly at $35^{\circ} \mathrm{C}$ (Fig. 3 , rows 13,15 ).

Since increased predicted stability of the acceptor and T-stems of tRNA ${ }^{\text {Ser(CGA) }}$ restores growth and prevents tRNA decay in a trm44- $\Delta$ tan1- $\Delta$ strain, destabilization of these same regions should result in exaggerated temperature sensitivity or lethality due to RTD. Consistent with this prediction, substitution of $\mathrm{A}_{7}: \mathrm{U}_{66}$ with $\mathrm{G}_{7}: \mathrm{U}_{66}$ reduces the predicted stability of tRNA ${ }^{\text {Ser(CGA) }}$ by $1.3 \mathrm{kcal} / \mathrm{mol}$ and causes lethality in a trm44- $\Delta$ tan $1-\Delta$ strain, and deletion of MET22 rescues growth up to $35^{\circ} \mathrm{C}$ (Figs. 3 [rows 15,22], 4A). Since a met22- $\Delta$ mutation phenocopies the effect of an xrn1- $\Delta$ rat1 double mutant in inhibiting several processing and degradation phenotypes, including RTD (Dichtl et al. 1997; Petfalski et al. 1998; Chernyakov et al. 2008), the met22- $\Delta$-mediated rescue of the exaggerated growth defect caused by the $\mathrm{G}_{7}: \mathrm{U}_{66}$ variant is almost certainly due to RTD.

The importance of the acceptor and T-stems to RTD substrate specificity extends to other $t R N A^{\text {Ser }}$ family members and fully modified $t R N A^{\text {Ser }}$

Based on our analysis of the acceptor and T-stems of tRNA $^{\text {Ser(CGA), it seemed likely that tRNA }}{ }^{\text {Ser(IGA) }}$ was resistant to RTD because of the high predicted stability of these stems. To test this prediction, we constructed

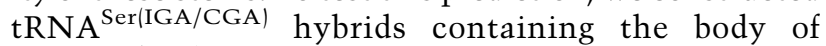
tRNA $^{\text {Ser(IGA) }}$ and the anti-codon loop (residues 3238) of tRNA ${ }^{\operatorname{Ser}(\mathrm{CGA})}$. As anticipated, the wild-type

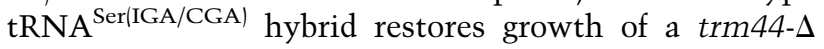
tan $1-\Delta$ strain at $37^{\circ} \mathrm{C}$ (Fig. $4 \mathrm{~B}$, row 2). In contrast, destabilization of the hybrid by substitution of $\mathrm{C}_{6}: \mathrm{G}_{67}$ with $\mathrm{U}_{6}: \mathrm{G}_{67}$ results in temperature-sensitive growth in the trm $44-\Delta \tan 1-\Delta$ strain at $35^{\circ} \mathrm{C}$ that is almost fully rescued by a met22- $\Delta$ mutation at $37^{\circ} \mathrm{C}$ (Fig. $4 \mathrm{~B}$, rows 4,6 ), indicating that the weakened tRNA ${ }^{\text {Ser(IGA/CGA) hybrid }}$ is a substrate for RTD. As observed with tRNA ${ }^{\text {Ser(CGA) }}$ variants, we found that further destabilization of the

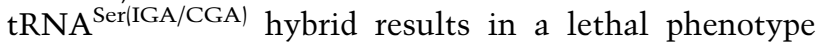
that is not rescued by a met22- $\Delta$ mutation. Since similar

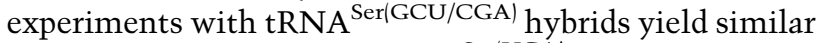
results (Fig. 3), and since tRNA ${ }^{\mathrm{Ser}(\mathrm{UGA})}$ is virtually identical to tRNA ${ }^{\text {Ser(CGA) }}$ and is similarly subject to RTD, we conclude that all four tRNA ${ }^{\text {Ser }}$ species require similar determinants to define them as substrates of the RTD pathway in a trm44- $\Delta$ tan1- $\Delta$ strain, albeit with slight idiosyncrasies.

We also found substantial evidence that the RTD pathway targets tRNA variants that are fully modified. Thus, a met22- $\Delta$ mutation suppresses or partially suppresses 

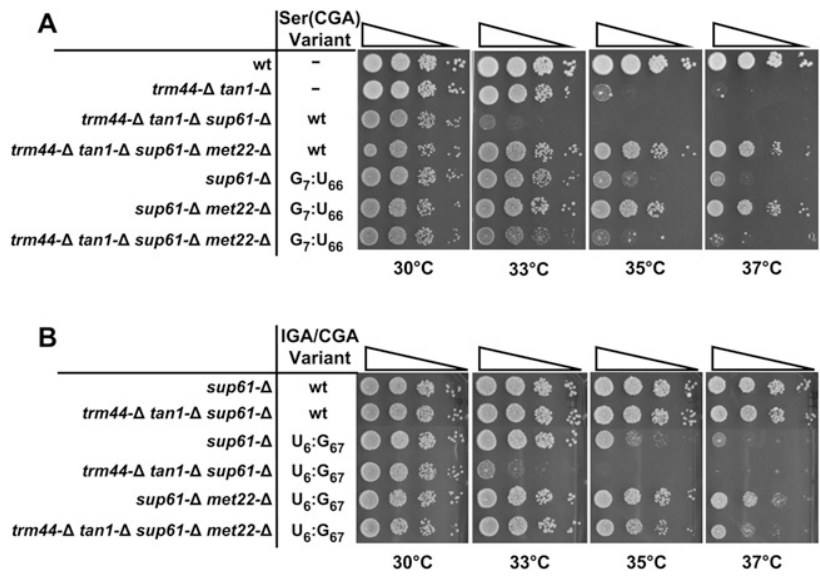

Figure 4. Destabilization of the acceptor stem of tRNA ${ }^{\text {Ser(CGA) }}$ and tRNA ${ }^{\mathrm{Ser}(\mathrm{IGA})}$ results in a temperature-sensitive growth defect that is rescued by a met22- $\Delta$ mutation. Strains were grown and sampled as in Figure 1B. (A) Substitution of $A_{7}: U_{66}$ by $\mathrm{G}_{7}: \mathrm{U}_{66}$ in tRNA $\mathrm{tr}^{\mathrm{Ser}(\mathrm{CGA})}$. (B) Substitution of $\mathrm{C}_{6}: \mathrm{G}_{67}$ by $\mathrm{U}_{6}: \mathrm{G}_{67}$ in tRNA ${ }^{\text {Ser(IGA/CGA). }}$

the growth defect of eight different tRNA ${ }^{\text {Ser }}$ variants in an otherwise wild-type background in which tRNAs are presumably fully modified, including four tRNA ${ }^{\text {Ser(CGA) }}$ variants with mutations at different positions of the acceptor stem (Fig. 3, rows $14,22,24,26)$, two tRNA ${ }^{\text {Ser(CGA) }}$ T-stem variants (Fig. 3 , rows 16,23), one tRNA ${ }^{\text {Ser(IGA/CGA) }}$ acceptor stem variant (Fig. 3, row 10), and one tRNA ${ }^{\text {Ser(GCU/CGA) }}$ acceptor stem variant (Fig. 3, row 21). These results provide strong evidence that RTD surveillance primarily monitors the stability of the acceptor and $\mathrm{T}$ stems of tRNA ${ }^{\text {Ser }}$ variants, and not necessarily modification status.

\section{RTD sensitivity of $t R N A^{\text {Ser(CGA) }}$ variants is predictable regardless of the position of the acceptor stem and T-stem mutations, and is modestly but predictably influenced by $a c^{4} \mathrm{C}$ and $\mathrm{Um}$}

A consideration of the results from all $28 \mathrm{tRNA}^{\text {Ser }}$ variants [as well as the wild-type tRNA ${ }^{\text {Ser(CGA) }}$ and the two wildtype hybrid tRNAs] underscores the importance of the acceptor and T-stems for RTD substrate recognition (Fig. 3). All eight variants that restore healthy growth to a trm44- $\Delta \tan 1-\Delta$ strain have among the highest predicted stabilities of their acceptor and T-stems, and each of the six variants in this group that were analyzed in vivo has stable levels of tRNA ${ }^{\text {Ser(CGA) }}$. Furthermore, 12 of the 19 variants that cause lethality or poor growth in either the wild-type or trm44- $\Delta$ tan 1- $\Delta$ strain are at least partially rescued by a met22- $\Delta$ mutation (one was not tested), and all but one of these has intermediate levels of predicted stability of the acceptor and T-stems. Moreover, of the seven variants that cause lethality or poor growth and are not rescued by a met22- $\Delta$ mutation in either strain, five are predicted to be among the least stable variants in the acceptor and T-stems (Fig. 3, rows 25,27,29-31), are less stable in these stems than any other cytoplasmic yeast tRNA (Supplemental Table S1), and are presumably below the level of permissible stability for the cell. We conclude that the strong correlation between growth phenotype conferred by a tRNA ${ }^{\text {Ser }}$ variant and the predicted stability of the acceptor and T-stems is primarily due to RTD.

This conclusion is reinforced by the variety of mutations we examined, which include alterations of six of the seven base pairs in the acceptor stem and three of the five base pairs in the T-stem, and various combinations of these changes with a range of predicted stabilities. Furthermore, almost all of the base pair changes within the acceptor stem and T-stem do not themselves perturb tRNA function, since tRNA ${ }^{\text {Ser(CGA) }}$ variants with seven of the nine altered base pairs in the acceptor or T-stem are functional in at least one variant combination (Fig. 3), and since one of the remaining two altered base pairs $\left(\mathrm{A}_{4}: \mathrm{U}_{69}\right.$ to $\left.\mathrm{C}_{4}: \mathrm{U}_{69}\right)$ is found in another tRNA ${ }^{\text {Ser }}$ species. Moreover, all six tRNA ${ }^{\text {Ser(GCU/CGA) }}$ and tRNA ${ }^{\text {Ser(IGA/CGA) acceptor and }}$ T-stem variants that were tested contain substitutions that are found in tRNA ${ }^{\text {Ser(CGA). }}$

Further examination of Figure 3 also indicates that the $\mathrm{Um}_{44}$ and $\mathrm{ac}^{4} \mathrm{C}_{12}$ modifications stabilize tRNA ${ }^{\text {Ser }}$, since, in the 16 cases where there is a growth difference between the wild-type and the corresponding trm44- $\Delta$ tan1- $\Delta$ strains, the wild-type strain invariably grows better. This is true for all three species of tRNA ${ }^{\text {Ser }}$ examined, and is true whether or not the strains also have a met22- $\Delta$ mutation. From a comparison of the predicted stabilities of variants with similar growth properties in a trm44- $\Delta$ $\tan 1-\Delta$ and a wild-type background, we infer that lack of $\mathrm{Um}_{44}$ and $\mathrm{ac}^{4} \mathrm{C}_{12}$ reduces the apparent stability of the acceptor and T-stems of tRNA ${ }^{\text {Ser }}$ by $\sim 1.0-1.5 \mathrm{kcal} / \mathrm{mol}$, although we argue below that this occurs as an indirect result of perturbation of tertiary structure.

We note that a trm44- $\Delta$ tan 1- $\Delta$ strain containing a wildtype tRNA ${ }^{\text {Ser(CGA) }}$ variant is unhealthy (temperaturesensitive at $33^{\circ} \mathrm{C}$ ) and near the limit for viability in our genetic screen (see Fig. 3, rows 15-31 in this background), yet is completely rescued by a met22- $\Delta$ mutation, whereas the corresponding wild-type strain with a wildtype tRNA ${ }^{\mathrm{Ser}(\mathrm{CGA})}$ variant is healthy at $37^{\circ} \mathrm{C}$. We therefore infer that, if variants have only very minor defects (of any type), they will cause lethality in a trm44- $\Delta$ tan1- $\Delta$ strain that is fully suppressed by a met22- $\Delta$ mutation, but will have no growth defect in a wild-type strain. Variants with this set of phenotypes can have only a minor role in RTD, at best. Of the strains listed in Figure 3, only the

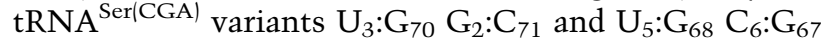
(Fig. 3, rows 11,19) have such a minor role in RTD, based on this consideration.

The anti-codon stem has no measurable effect on RTD specificity, and the variable stem has a limited effect

Contrary to our observations with variants in the acceptor and T-stems, stabilization of the tRNA ${ }^{\text {Ser(CGA) }}$ anti-codon stem by substitution of either $\mathrm{A}_{27}: \mathrm{U}_{43}$ or $\mathrm{A}_{29}: \mathrm{U}_{41}$ with the corresponding $\mathrm{G}: \mathrm{C}$ pair does not measurably rescue the growth defect of a trm44- $\Delta$ tan1- $\Delta$ strain (Table 1, cf. row 1 and rows 2,3 ). Indeed, an anti-codon stem containing both of these G:C substitutions also does not measurably 
Table 1. Analysis of $t R N A^{\operatorname{Ser}(C G A)}$ variants with substitutions outside the acceptor stem and T-stem

\begin{tabular}{|c|c|c|c|c|c|c|c|c|}
\hline \multirow[b]{3}{*}{ Row } & \multirow{3}{*}{$\begin{array}{l}\text { Serine } \\
\text { species }\end{array}$} & & & \multirow{3}{*}{$\begin{array}{l}\text { tRNA } \\
\text { stem }\end{array}$} & \multicolumn{4}{|c|}{ Viability of strain expressing variant } \\
\hline & & \multicolumn{2}{|c|}{ Base pairing } & & \multirow{2}{*}{\multicolumn{2}{|c|}{$\begin{array}{c}\operatorname{trm} 44-\Delta^{\mathrm{a}} \\
\tan 1-\Delta \\
\operatorname{met} 22-\Delta\end{array}$}} & \multirow[b]{2}{*}{ Wild type $^{\mathrm{a}}$} & \multirow[b]{2}{*}{$\operatorname{met} 22-\Delta^{\mathrm{a}}$} \\
\hline & & Wild type & Variant & & & & & \\
\hline 1 & CGA & wild type & wild type & & $+++30^{\circ} \mathrm{C}$ & $+++37^{\circ} \mathrm{C}$ & $+++37^{\circ} \mathrm{C}$ & $\mathrm{N} / \mathrm{A}$ \\
\hline 2 & CGA & $\mathrm{A}_{27}: \mathrm{U}_{43}$ & $\mathrm{G}_{27}: \mathrm{C}_{43}$ & Anti-codon & $+++30^{\circ} \mathrm{C}$ & $+++37^{\circ} \mathrm{C}$ & $+++37^{\circ} \mathrm{C}$ & $\mathrm{N} / \mathrm{A}$ \\
\hline 3 & CGA & $\mathrm{A}_{29}: \mathrm{U}_{41}$ & $\mathrm{G}_{29}: \mathrm{C}_{41}$ & Anti-codon & $+++30^{\circ} \mathrm{C}$ & $+++37^{\circ} \mathrm{C}$ & $+++37^{\circ} \mathrm{C}$ & $\mathrm{N} / \mathrm{A}$ \\
\hline 4 & CGA & $\mathrm{A}_{27}: \mathrm{U}_{43} \quad \mathrm{~A}_{29}: \mathrm{U}_{41}$ & $\mathrm{G}_{27}: \mathrm{C}_{43} \mathrm{G}_{29}: \mathrm{C}_{41}$ & Anti-codon & $+++30^{\circ} \mathrm{C}$ & $+++37^{\circ} \mathrm{C}$ & $+++37^{\circ} \mathrm{C}$ & $\mathrm{N} / \mathrm{A}$ \\
\hline 5 & CGA & $\mathrm{C}_{\mathrm{e} 3}: \mathrm{G}_{\mathrm{e} 7}$ & $\mathrm{U}_{\mathrm{e} 3}: \mathrm{A}_{\mathrm{e} 7}$ & Variable & Lethal & $+++37^{\circ} \mathrm{C}$ & $+++37^{\circ} \mathrm{C}$ & $\mathrm{N} / \mathrm{A}$ \\
\hline 6 & CGA & $\mathrm{C}_{\mathrm{e} 5}$ & $\mathrm{U}_{\mathrm{e} 5}$ & Variable & Lethal & $+++37^{\circ} \mathrm{C}$ & $+++37^{\circ} \mathrm{C}$ & $\mathrm{N} / \mathrm{A}$ \\
\hline 7 & CGA & $\mathrm{C}_{\mathrm{e} 3}: \mathrm{G}_{\mathrm{e} 7} \mathrm{C}_{\mathrm{e} 5}$ & $\mathrm{U}_{\mathrm{e} 3}: \mathrm{A}_{\mathrm{e} 7} \mathrm{U}_{\mathrm{e} 5}$ & Variable & Lethal & $+++37^{\circ} \mathrm{C}$ & $+++37^{\circ} \mathrm{C}$ & N/A \\
\hline 8 & CGA & $\mathrm{G}_{45}: \mathrm{C}_{46}$ & $\mathrm{G}_{45}: \mathrm{U}_{46}$ & Variable & Lethal & $++33^{\circ} \mathrm{C}_{1}^{\mathrm{b}}+35^{\circ} \mathrm{C}$ & $++33^{\circ} \mathrm{C}^{\mathrm{b}}+35^{\circ} \mathrm{C}$ & $+++33^{\circ} \mathrm{C}^{\mathrm{b}}++35^{\circ} \mathrm{C}$ \\
\hline 9 & CGA & $\mathrm{G}_{45}: \mathrm{C}_{46} \mathrm{C}_{\mathrm{e} 3}: \mathrm{G}_{\mathrm{e} 7}$ & $\mathrm{G}_{45}: \mathrm{U}_{46} \mathrm{U}_{\mathrm{e} 3}: \mathrm{A}_{\mathrm{e} 7}$ & Variable & Lethal & $++25^{\circ} \mathrm{C}_{1}^{\mathrm{b}}+30^{\circ} \mathrm{C}$ & $++33^{\circ} \mathrm{C}_{1}^{\mathrm{b}}+35^{\circ} \mathrm{C}$ & $++33^{\circ} \mathrm{C}_{1}^{\mathrm{b}}+35^{\circ} \mathrm{C}$ \\
\hline 10 & CGA & $\begin{array}{l}\mathrm{G}_{45}: \mathrm{C}_{46} \\
\quad \mathrm{C}_{\mathrm{e} 3}: \mathrm{G}_{\mathrm{e} 7} \mathrm{C}_{\mathrm{e} 5}\end{array}$ & $\begin{array}{l}\mathrm{G}_{45}: \mathrm{U}_{46} \\
\mathrm{U}_{\mathrm{e} 3}: \mathrm{A}_{\mathrm{e} 7} \mathrm{U}_{\mathrm{e} 5}\end{array}$ & Variable & Lethal & Lethal & $++25^{\circ} \mathrm{C}^{\mathrm{b}}+30^{\circ} \mathrm{C}$ & $++33^{\circ} \mathrm{C}^{\mathrm{b}}+35^{\circ} \mathrm{C}$ \\
\hline 11 & CGA & $\mathrm{C}_{11}: \mathrm{G}_{24}$ & $\mathrm{U}_{11}: \mathrm{G}_{24}$ & $\mathrm{D}$ & Lethal & Lethal & Lethal & Lethal \\
\hline 12 & CGA & $\mathrm{G}_{13}$ & $\mathrm{U}_{13}: \mathrm{A}_{22}$ & $\mathrm{D}$ & Lethal & Lethal & Lethal & Lethal \\
\hline
\end{tabular}

${ }^{a}$ Values indicate the highest temperature at which growth was observed.

${ }^{b}$ Values indicate growth at the next lowest temperature tested.

(N/A) Strain not made, since no suppression could be scored.

restore growth in a trm $44-\Delta \tan 1-\Delta$ strain (Table 1 , row 4), despite substantial predicted stabilization $(3.8 \mathrm{kcal} / \mathrm{mol})$ of this stem. The lack of involvement of the anti-codon stem in RTD is consistent with the initiation of RTD by a $5^{\prime}-3^{\prime}$ exonuclease and the lack of known interactions of this stem with other portions of the tRNA molecule.

The variable arm also appears to have only a modest effect on RTD substrate recognition. Because the variable stem is comprised entirely of G:C base pairs, we could analyze only destabilizing mutations and mutations in the loop. Since substitution of $\mathrm{C}_{\mathrm{e} 3}: \mathrm{G}_{\mathrm{e} 7}$ by $\mathrm{U}_{\mathrm{e} 3}: \mathrm{A}_{\mathrm{e} 7}$ (and/or replacement of $\mathrm{C}_{\mathrm{e} 5}$ by $\mathrm{U}_{\mathrm{e} 5}$ ) causes lethality in a trm $44-\Delta$ tan1- $\Delta$ strain that is rescued by a met22- $\Delta$ mutation, but causes no phenotype in wild-type cells (Table 1, rows 5-7), its RTD effect is modest, as we argued above. However, replacement of $\mathrm{G}_{45}: \mathrm{C}_{46}$ by $\mathrm{G}_{45}: \mathrm{U}_{46}$ impairs growth in a wild-type strain and is very modestly suppressed by a met22- $\Delta$ mutation (Table 1 , row 8 ). This result suggests that the $\mathrm{G}_{45}: \mathrm{U}_{46}$ substitution inhibits tRNA function by a mechanism that is primarily independent of RTD, although a small portion can be ascribed to RTD. Since this limited RTD effect of the $\mathrm{G}_{45}: \mathrm{U}_{46}$ substitution in wildtype cells is modestly increased if the tRNA also has both the $\mathrm{U}_{\mathrm{e} 3}: \mathrm{A}_{\mathrm{e} 7}$ and the $\mathrm{U}_{\mathrm{e} 5}$ mutations (Table 1, row 10 but not row 91, we conclude that the variable arm has a distinct but limited role in RTD, unless wholesale changes are made to the arm.

Comparable experiments in the D-stem-loop were inconclusive, since lethal phenotypes were observed by the substitutions we tested, which were not suppressed by a met22- $\Delta$ mutation (Table 1 ).

\section{A destabilizing mutation in the T-stem of a $t R N A^{T y r}$ species elicits RTD}

We also provide evidence that SUP4- $3 \mathrm{am}^{\text {ts }}$ strains (RasseMessenguy and Fink 1973) are temperature-sensitive for suppression because the tRNA ${ }^{\text {Tyr }}$ suppressor encoded by SUP4 in this strain is degraded by RTD. Thus, SUP4-3am ${ }^{\text {ts }}$ strains suppress the auxotrophy of his4-am and trp1-am nonsense mutations at $30^{\circ} \mathrm{C}$ and $25^{\circ} \mathrm{C}$ but not at $35^{\circ} \mathrm{C}$, whereas deletion of MET22 restores suppression of both mutations up to $37^{\circ} \mathrm{C}$ (Supplemental Fig. S2). We quantitatively evaluated suppression using a dual luciferase reporter, with a nonsense amber (UAG) or ochre (UAA) codon between the firefly and Renilla luciferase genes (Salas-Marco and Bedwell 2005). At $25^{\circ} \mathrm{C}$, suppression in a SUP4-3am ${ }^{\text {ts }}$ strain is $7.6 \%$ efficient, similar to that observed for a control SUP4-1oc suppressor and substantially more than background $(0.35 \%)$, whereas, at $35^{\circ} \mathrm{C}$, suppression is at $0.46 \%$, near background levels (Table 2 ). Consistent with our plating results, a met22- $\Delta$ mutation improves suppression by SUP4-3am ${ }^{\text {ts }}$ from $0.46 \%$ to $2.9 \%$ at $35^{\circ} \mathrm{C}$, and from $7.6 \%$ to $22.0 \%$ at $25^{\circ} \mathrm{C}$ (Table 2). In addition to the expected CUA anti-codon, we found that the SUP4-3am ${ }^{\text {ts }}$ allele has a $\mathrm{C}_{52}: \mathrm{C}_{62}$ mismatch in the T-stem (instead of $\mathrm{C}_{52}: \mathrm{G}_{62}$ ) that is predicted to destabilize the acceptor and T-stems from -26.2 to $-18.9 \mathrm{kcal} / \mathrm{mol}$ (Supplemental Table S1), and separate experiments show that temperature-sensitive suppression requires this mismatch (data not shown).

Table 2. Deletion of MET22 restores suppression by SUP4-3 ${ }^{\text {ts }}$ at the nonpermissive temperature

\begin{tabular}{|c|c|c|c|}
\hline \multirow[b]{2}{*}{ Strain } & \multirow{2}{*}{$\begin{array}{l}\text { Rluc-Fluc } \\
\text { construct }\end{array}$} & \multicolumn{2}{|c|}{ Readthrough } \\
\hline & & $25^{\circ} \mathrm{C}$ & $35^{\circ} \mathrm{C}$ \\
\hline Wild type & UAA & $0.22 \% \pm 0.03 \%$ & $\mathrm{~N} / \mathrm{D}$ \\
\hline SUP4-1 & UAA & $7.4 \% \pm 1.9 \%$ & $\mathrm{~N} / \mathrm{D}$ \\
\hline Wild type & UAG & $0.35 \% \pm 0.09 \%$ & $0.35 \% \pm 0.05 \%$ \\
\hline$S U P 4-3^{\text {ts }}$ & UAG & $7.6 \% \pm 0.9 \%$ & $0.46 \% \pm 0.06 \%$ \\
\hline SUP4-3 ${ }^{\text {ts }}$ met22- $\Delta$ & UAG & $22.0 \% \pm 1.9 \%$ & $2.9 \% \pm 0.42 \%$ \\
\hline
\end{tabular}

(N/D) Not determined. 
$R T D$ sensitivity of $t R N A^{\operatorname{Ser}(C G A)}$ variants is correlated with a more accessible acceptor stem and T-stem and a more exposed $5^{\prime}$ end

To explicitly demonstrate that the acceptor and T-stems of substrate tRNAs have biochemical properties that would promote degradation by the RTD pathway, we examined three representative purified tRNA ${ }^{\mathrm{Ser}(\mathrm{CGA})}$ species from both wild-type and trm44- $\Delta$ tan1- $\Delta$ strains with widely varying ranges of predicted acceptor and T-stem stability and corresponding susceptibility to RTD: tRNA ${ }^{\text {Ser(CGA) }}$ $\mathrm{G}_{2}: \mathrm{C}_{71} \quad \mathrm{C}_{6}: \mathrm{G}_{67}(-22.1 \mathrm{kcal} / \mathrm{mol})$, which is resistant to RTD in both trm44- $\Delta$ tan1- $\Delta$ and wild-type strains; wildtype tRNA ${ }^{\text {Ser(CGA) }}(-17.1 \mathrm{kcal} / \mathrm{mol})$, which is only sensitive to RTD in a trm44- $\Delta$ tan1- $\Delta$ strain; and tRNA ${ }^{\text {Ser(CGA) }}$ $\mathrm{G}_{7}: \mathrm{U}_{66}(-15.8 \mathrm{kcal} / \mathrm{mol})$, which is sensitive to RTD in both strains. All of these purified tRNA species have the full complement of expected modifications (data not shown).

Structure probing with RNase T2 reveals that RTD substrate tRNAs are more sensitive to cleavage than nonsubstrate tRNAs in the acceptor stem and the T-stem and loop. In the absence of $\mathrm{Mg}^{++}$, both tRNA ${ }^{\text {Ser(CGA) }} \mathrm{G}_{7}: \mathrm{U}_{66}$ and wild-type tRNA ${ }^{\text {Ser(CGA) }}$ are cleaved throughout the acceptor and T-stems at $45^{\circ} \mathrm{C}$ and $50^{\circ} \mathrm{C}$ and are equally sensitive whether derived from wild-type or trm44- $\Delta$ tan 1- $\Delta$ strains (Fig. 5A), whereas the nonsubstrate tRNA $^{\text {Ser(CGA) }} \quad G_{2}: \mathrm{C}_{71} \quad \mathrm{C}_{6}: \mathrm{G}_{67}$ is uniformly RNase T2resistant. The tRNAs are likely folded correctly under these conditions, since, as expected, the anti-codon loop and T-loop are the regions most sensitive to RNase T2 (Supplemental Fig. S3). These results show that all three RTD substrates are the most sensitive to cleavage, along with the nonsubstrate wild-type tRNA from a wild-type strain. Furthermore, this increased RNase $\mathrm{T} 2$ sensitivity is confined to the acceptor stem and T-stem-loop, and not the variable stem or the anti-codon stem, indicating a localized change in conformation in this region (Supplemental Fig. S3).
In the presence of $1 \mathrm{mM} \mathrm{Mg}^{++}$, the T-loops of fully modified tRNA ${ }^{\text {Ser(CGA) }} \mathrm{G}_{7}: \mathrm{U}_{66}$ and wild-type tRNA ${ }^{\text {Ser(CGA) }}$ are more resistant to RNase T2 than the corresponding tRNAs from trm $44-\Delta \tan 1-\Delta$ cells at either $35^{\circ} \mathrm{C}$ (Fig. $5 \mathrm{~B}$ ) or $30^{\circ} \mathrm{C}$ (Supplemental Fig. S4). These results suggest that the presence of both the $\mathrm{ac}^{4} \mathrm{C}$ and Um modifications and $\mathrm{Mg}^{++}$stabilizes the tRNA structure through tertiary interactions, consistent with previous analysis of tRNAs with and without bulk modifications (Hall et al. 1989; Yue et al. 1994). However, we again cannot discriminate between tRNA ${ }^{\text {Ser(CGA) }} \mathrm{G}_{7}: \mathrm{U}_{66}$ (substrate) and wild-type tRNA $^{\text {Ser(CGA) }}$ (nonsubstrate) from wild-type cells. These results thus demonstrate that RNase T2 sensitivity discriminates five of the six tRNAs examined with respect to their RTD sensitivity.

Structure probing with calf intestinal phosphatase (CIP) suggests that the degree of exposure of the $5^{\prime}$ ends of RTD substrates directly matches their RTD sensitivity and the lower predicted stability of their acceptor and T-stems. We used CIP to probe the 5' end of tRNAs, since this enzyme, while nonspecific, can discriminate phosphates based on accessibility (McCraith and Phizicky 1990). We found that tRNA ${ }^{\text {Ser(CGA) }} G_{7}: U_{66}$ is the most sensitive species, wild-type tRNA ${ }^{\mathrm{Ser}(\mathrm{CGA})}$ is the next most sensitive species, tRNA ${ }^{\text {Ser(CGA) }} \mathrm{G}_{2}: \mathrm{C}_{71} \mathrm{C}_{6}: \mathrm{G}_{67}$ is the least sensitive species, and tRNA from trm44- $\Delta$ tan1- $\Delta$ cells is much more sensitive than that from wild-type cells for both RTD substrates (Fig. 6A). Similarly, we found that improved stability of the T-stem also makes the 5' end of the tRNA less accessible, since the $\mathrm{A}_{51}: \mathrm{U}_{63}$ variant is more resistant to CIP than wild-type tRNA ${ }^{\text {Ser(CGA) }}$ (Fig. 6B). Because of the strict correlation between CIP sensitivity, RTD sensitivity, and predicted lower stability of the acceptor and $\mathrm{T}$-stems, these results suggest strongly that selective $5^{\prime}-3^{\prime}$ degradation of RTD substrates by Xrn 1 and Rat 1 is due to selective exposure of the $5^{\prime}$ end to attack.
A

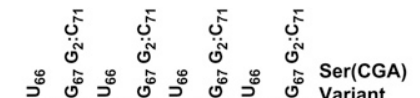
$\geq 0$. 030030030030 …++++++ +++ RNase T2

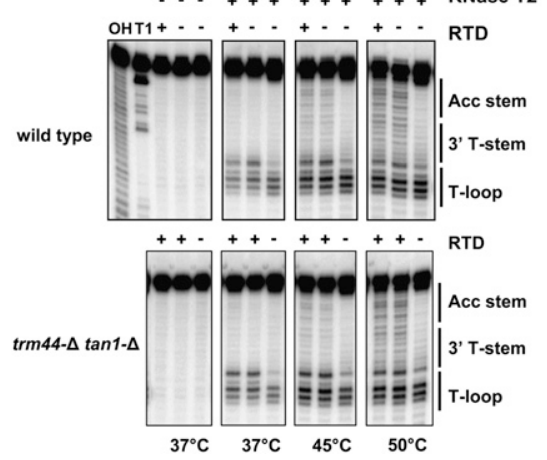

B

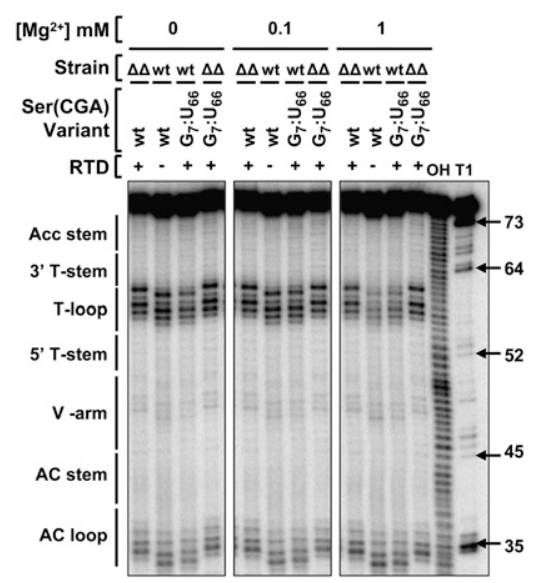

Figure 5. tRNA $^{\text {Ser(CGA) }}$ variants that are RTD substrates are more sensitive than nonsubstrates to RNase $\mathrm{T} 2$ cleavage in the acceptor stem and T-stem-loop. (A) Analysis of tRNA ${ }^{\text {Ser(CGA) }}$ variants in the absence of $\mathrm{Mg}^{++}$. tRNAs were purified, $5^{\prime}$-end labeled, and treated with RNase $\mathrm{T} 2$ at $37^{\circ} \mathrm{C}$, $45^{\circ} \mathrm{C}$, or $50^{\circ} \mathrm{C}$, and products were resolved by PAGE. Analyses of tRNAs from wildtype strains (top panels) and trm44- $\Delta$ tan $1-\Delta$ strains (bottom panels) are from the same experiment and gel. $(\mathrm{OH})$ Base hydrolysis ladder of tRNA ${ }^{\text {Ser(CGA) }}$ from trm44- $\Delta$ tan1- $\Delta$ cells; (T1) RNase T1 ladder; (arrows) positions of selected cleavage products; (bars) regions of the tRNA secondary structure. $(B)$ Analysis of tRNA variants from wild-type and trm44- $\Delta$ tan $1-\Delta$ strains in the presence of $\mathrm{Mg}^{++}$. tRNAs were analyzed for RNase T2 sensitivity at $35^{\circ} \mathrm{C}$ in the presence of the indicated concentrations of $\mathrm{MgCl}_{2}$, as described in $A$. ( $\Delta \Delta$ and wt) tRNAs from trm44- $\Delta$ tan1- $\Delta$ and wild-type cells, respectively. Note that tRNA from wild-type cells migrates faster than tRNA from a trm44- $\Delta$ tan1- $\Delta$ strain, presumably due to the additional modifications. 
Whipple et al.

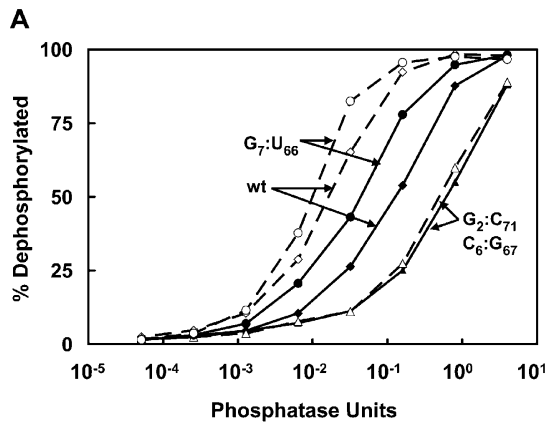

B

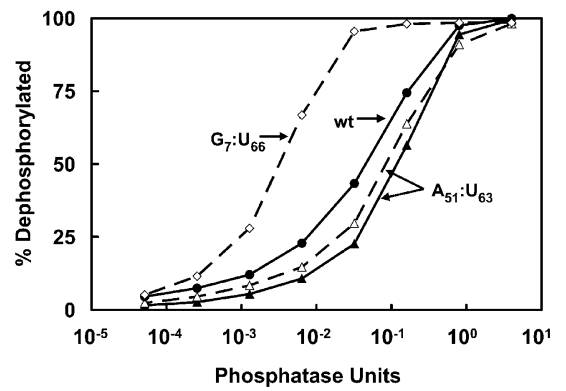

Figure 6. tRNA $^{\mathrm{Ser}(\mathrm{CGA})}$ variants that are substrates for RTD are more sensitive than nonsubstrates to removal of a $5^{\prime}$ phosphate. (A) Analysis of tRNA ${ }^{\text {Ser(CGA) }}$ acceptor stem variants. tRNA ${ }^{\text {Ser(CGA) }}$ variants purified from wild-type and trm $44-\Delta \tan 1-\Delta$ strains were $5^{\prime}$ end-labeled and treated with CIP as indicated, and released phosphate was separated from tRNA by TLC and quantified. (Dashed lines) tRNA from trm44- $\Delta$ tan1- $\Delta$ cells; (solid lines) tRNA from wild-type cells. $(B)$ Analysis of tRNA ${ }^{\text {Ser(CGA) }}$ T-stem variant $\mathrm{A}_{51}: \mathrm{U}_{63}$.

\section{Xrn1 acts on $t R N A^{\text {Ser(CGA) }}$ RTD substrates in vivo} and in vitro

To determine the role of $5^{\prime}-3^{\prime}$ exonucleases in the degradation of $\mathrm{tRNA}^{\mathrm{Ser}(\mathrm{CGA})}$ in vivo, we examined the effect of an $x r n 1-\Delta$ mutation in a trm44- $\Delta \tan 1-\Delta$ strain. We found that the temperature sensitivity of the trm44- $\Delta$ tan $1-\Delta$ strain is almost completely rescued by an xrn1- $\Delta$ mutation at $37^{\circ} \mathrm{C}$ (Supplemental Fig. S5A), and that tRNA ${ }^{\text {Ser(CGA) }}$ and tRNA ${ }^{\text {Ser(UGA) }}$ are almost completely stable in these strains (Supplemental Fig. S5B,C), suggesting that most of the RTD in a trm44- $\Delta$ tan 1- $\Delta$ strain is due to Xrn1.

To examine the role of Xrn 1 directly, we purified Xrn1 and analyzed its activity with the same set of RTD substrate and nonsubstrate tRNAs analyzed with RNase T2 and CIP. We found that the sensitivity of $3^{\prime}$ endlabeled tRNAs to Xrn1 digestion exactly parallels sensitivity to CIP treatment and growth phenotype in all six tRNA species tested (Fig. 7). Thus, tRNA ${ }^{\text {Ser(CGA) }} \mathrm{G}_{7}: \mathrm{U}_{66}$ from trm44- $\Delta$ tan 1- $\Delta$ cells is the most sensitive to Xrn1 cleavage, with $86 \%$ of the full-length tRNA partially or completely degraded, followed by tRNA ${ }^{\text {Ser(CGA) from }}$ a trm44- $\Delta$ tan1- $\Delta$ strain, tRNA ${ }^{\text {Ser(CGA) }} \mathrm{G}_{7}: \mathrm{U}_{66}$ from wildtype cells, tRNA ${ }^{\text {Ser(CGA) }}$ from wild-type cells, and then tRNA $^{\text {Ser(CGA) }} \mathrm{G}_{2}: \mathrm{C}_{71} \mathrm{C}_{6}: \mathrm{G}_{67}$ from either strain (Fig. 7). In each case, most of the observed product appears to be $\mathrm{pCp}$, based on size, while treatment with a mock purification fraction yields no degradation (Fig. 7). These results exactly match the order of sensitivity observed with CIP (cf. Figs. 7 and $6 \mathrm{~A})$.

We also found that Xrnl degrades tRNA ${ }^{\text {Val(AAC) }}$ from trm8- $\Delta$ trm4- $\Delta$ cells much more efficiently than tRNA $^{\text {Val(AAC) }}$ from wild-type cells (Supplemental Fig. S6). This result demonstrates that the discrimination of RTD substrates by Xrn 1 in vitro extends to other tRNAs known to be subject to this pathway (Chernyakov et al. 2008).

\section{Discussion}

Here, we provided evidence that the RTD pathway acts to degrade substrate tRNAs that have slipped below a critical threshold of stability through mutation in their acceptor stem or T-stem or lack of certain modifications. The predicted stability of the acceptor and T-stems in the

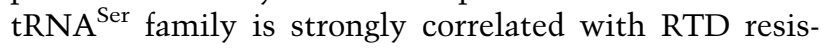
tance, as measured by growth and in vivo stability of stabilizing tRNA variants, for a large number of variants containing different acceptor and T-stem mutations. Furthermore, sensitivity to RTD directly correlates with sensitivity of tRNA variants to RNase T2 in the acceptor stem and T-stem-loop region, exposure of the $5^{\prime}$ end to phosphatase, and sensitivity to degradation by purified Xrn1. Thus, we conclude that a primary reason that RTD occurs in vivo is because of a less stable acceptor and T-stem, resulting in exposure of the $5^{\prime}$ end of tRNA to attack by Xrn1 or Rat1. We note, however, that these conclusions do not take into account the role of charging in substrate recognition by RTD, since our in vitro

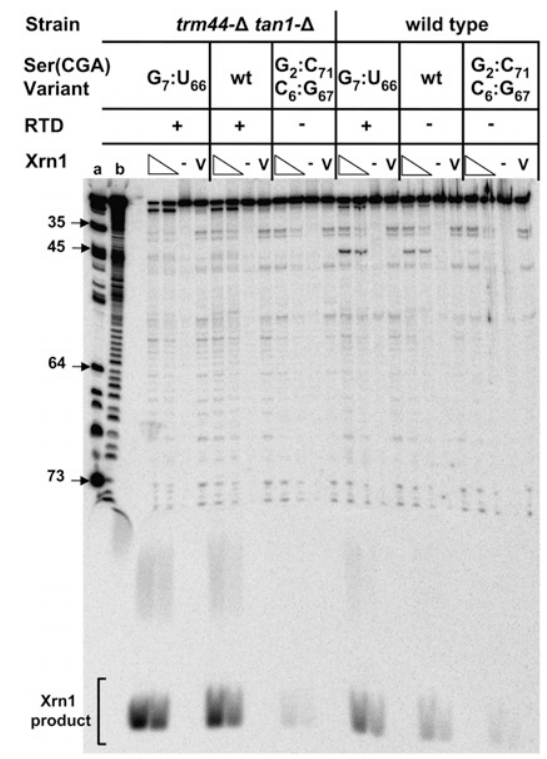

Figure 7. Xrnl degrades RTD substrate tRNAs in vitro with the same specificity as RTD in vivo. Purified tRNA ${ }^{\text {Ser(CGA) }}$ variants were $3^{\prime}$ end-labeled and treated with the indicated amounts of purified Xrn1, and products were resolved on a $20 \%$ polyacrylamide/7M urea gel. (-) buffer only; (v) equivalent volume of mock purification; (a) RNase $\mathrm{T} 1$; (b) base hydrolysis ladder. 
analysis employs uncharged tRNAs and we were not able to assess the charging state of tRNA ${ }^{\text {Ser }}$ species in vivo.

Our data suggest that the modifications $\mathrm{ac}^{4} \mathrm{C}_{12}$ and $\mathrm{Um}_{44}$ are not acting as specific determinants for recognition by RTD, but are instead promoting acceptor and T-stem stability through enhanced tertiary structure stability. Thus, fully modified tRNA ${ }^{\mathrm{Ser}(\mathrm{CGA})}$ from a wildtype strain is more resistant to RNase T2 cleavage in the T-loop than tRNA from a tan1- $\Delta$ trm $44-\Delta$ strain, and this increased resistance requires $\mathrm{Mg}^{++}$(Fig. 5B). These data are consistent with the known participation of the T-loop in tertiary interactions that stabilize the tertiary fold (Jack et al. 1976; Westhof et al. 1985; Basavappa and Sigler 1991; Biou et al. 1994) and with the well-documented roles that both $\mathrm{Mg}^{++}$and bulk modifications play in stabilizing tRNA tertiary interactions (Hall et al. 1989; Yue et al. 1994). We therefore suggest that lack of $\mathrm{ac}^{4} \mathrm{C}_{12}$ and $\mathrm{Um}_{44}$ weakens the tRNA tertiary structure, which is known to melt first in a variety of tRNAs (see Shelton et al. 2001 and references therein), resulting in a shift of the equilibrium of the relatively unstable acceptor stem and T-stem of tRNA ${ }^{\text {Ser(CGA) }}$ toward an unfolded state, thereby increasing $5^{\prime}$ end accessibility for degradation by Xrn1. This interpretation is further supported by our data showing that tRNA from a trm44- $\Delta$ tan1- $\Delta$ strain has a more exposed $5^{\prime}$ phosphate and is more readily degraded by Xrn1 in vitro, as well as by the additional $1.0-1.5 \mathrm{kcal} /$ mol that these modifications appear to contribute to the predicted stability of the acceptor stem and T-stem (Fig. 3).

It seems likely that $\mathrm{Um}_{44}$ is involved in tertiary interactions with $\mathrm{m}^{2,2} \mathrm{G}_{26}$, since a noncanonical pair between $\mathrm{N}_{44}$ and $\mathrm{N}_{26}$ is found in yeast tRNA ${ }^{\text {Phe }}$ and tRNA ${ }^{\text {Asp }}$ (Jack et al. 1976; Westhof et al. 1985) and in tRNA ${ }^{\text {Ser }}$ from Thermus thermophilus, which, like tRNA ${ }^{\text {Ser }}$ from yeast, has a long variable arm (Biou et al. 1994). While the role of $\mathrm{ac}^{4} \mathrm{C}_{12}$ is not as clearly defined, the $\mathrm{U}_{12}$ D-stem partner $\mathrm{A}_{23}$ interacts with $\mathrm{A}_{9}$ in yeast $\mathrm{tRNA}^{\text {Phe }}$ and tRNA ${ }^{\text {Asp }}$ (Jack et al. 1976; Westhof et al. 1985), and, in tRNA ${ }^{\text {Ser }}$ from T. thermophilus, there is a tertiary interaction between the adjacent $\mathrm{G}_{13}$ residue and $\mathrm{G}_{9}$ (Biou et al. 1994). Furthermore, $\mathrm{ac}^{4} \mathrm{C}$ favors the $3^{\prime}$ endo formation (Kawai et al. 1989), which likely enhances the stability of helices, and the acetyl group is not likely to interfere with WatsonCrick pairing (Parthasarathy et al. 1978).

By extension, we suggest that lack of $\mathrm{m}^{7} \mathrm{G}_{46}$ and $\mathrm{m}^{5} \mathrm{C}_{49}$ elicits RTD in trm8- $\Delta$ trm4- $\Delta$ mutants by destabilizing tertiary interactions in tRNA ${ }^{\mathrm{Val}(\mathrm{AAC})}$, resulting in weaker acceptor and T-stems. $\mathrm{m}^{7} \mathrm{G}_{46}$ and $\mathrm{A}_{46}$ are known to interact with $\mathrm{N}_{22}$ in tRNA $^{\text {Phe }}$ and tRNA ${ }^{\text {Asp }}$ (Jack et al. 1976; Westhof et al. 1985), and $\mathrm{m}^{5} \mathrm{C}_{49}$ is known to modestly stabilize folding of yeast tRNA ${ }^{\text {Phe }}$ half-molecules (Nobles et al. 2002). The observation that RTD occurs on tRNA ${ }^{\mathrm{Val}(\mathrm{AAC})}$ and not on tRNA ${ }^{\mathrm{Val}(\mathrm{CAC})}$ and $\mathrm{tRNA}_{i}{ }^{\text {Met }}$ (which also normally have $\mathrm{m}^{7} \mathrm{G}_{46}$ and $\mathrm{m}^{5} \mathrm{C}_{49}$ ) is consistent with the more stable predicted acceptor and T-stems of tRNA ${ }^{\mathrm{Val}(\mathrm{CAC})}$ and $\mathrm{tRNA}_{\mathrm{i}}{ }^{\text {Met }}$ (Supplemental Table S1). However, it is more difficult to explain why RTD does not occur on tRNA ${ }^{\text {Phe }}$ (which also normally has $\mathrm{m}^{7} \mathrm{G}_{46}$ and $\mathrm{m}^{5} \mathrm{C}_{49}$ ), since its acceptor and T-stems are predicted to be significantly less stable than those of
tRNA $^{\mathrm{Val}(\mathrm{AAC})}$ (Supplemental Table S1). Perhaps the lack of $\mathrm{m}^{7} \mathrm{G}_{46}$ and $\mathrm{m}^{5} \mathrm{C}_{49}$ is particularly deleterious to the tertiary structure of tRNA ${ }^{\mathrm{Val}(\mathrm{AAC})}$ relative to that of tRNA ${ }^{\text {Phe }}$.

Based on our results, we speculate that tRNAs are nearly completely modified in the tRNA body in vivo, in part because hypomodification results in reduced half-life of the tRNA due to RTD. We further speculate that each tRNA species in the cell can be subject to RTD if appropriately destabilized in the acceptor or T-stem. We note that, among yeast tRNAs, there appears to be a lower threshold of predicted stability for functional acceptor and T-stems, and that tRNA ${ }^{\text {Ser(CGA) }}$ and the nearly identical tRNA ${ }^{\text {Ser(UGA) }}$ are among the least stable species (Supplemental Table S1), along with $\mathrm{tRNA}^{\mathrm{Met}}, \mathrm{tRNA}^{\mathrm{Ala}(\mathrm{UGC})}$,

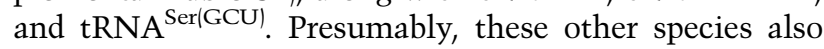
have stabilizing modifications or other structural features that prevent their turnover in the cell.

Our results suggest that the existence of RTD imposes an evolutionary constraint on tRNA function, in addition to other known evolutionary pressures on tRNA function. Overwhelming evidence supports the second genetic code, in which individual tRNAs have evolved with their cognate aminoacyl tRNA synthetases to ensure accurate charging through unique determinants in the anti-codon, the acceptor helix, or other sites, which sometimes involve modified residues (Muramatsu et al. 1988; MusierForsyth et al. 1991; Giege et al. 1998). In addition, there is substantial evidence that aminoacylated tRNAs have evolved for uniform binding of EF-Tu (LaRiviere et al. 2001; Schrader et al. 2009) and the ribosome (Fahlman et al. 2004; Olejniczak et al. 2005), and for uniform use in each of the steps of translation (Ledoux and Uhlenbeck 2008). The results reported here suggest that tRNAs have also evolved in eukaryotes to be stable enough to resist degradation by RTD through a sufficiently stable acceptor and T-stem and tertiary structure, while still functioning as unique species for recognition and charging and as similar species for steps in translation.

It is also clear from our results that massive base pair changes can be tolerated in some of the stems of tRNA $^{\text {Ser(CGA) }}$. Healthy growth is maintained when

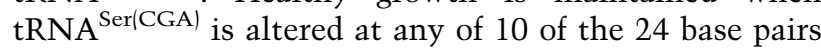
(of 12 tested), and the two cases in which an altered base pair fails to function have not been fully examined. In contrast, a similar study of tRNA ${ }^{\mathrm{Arg}(\mathrm{CCG})}$ reveals a number of D-loop residues that could not be altered (Geslain et al. 2003). The high level of variance that is tolerated in the base pairs of $\mathrm{tRNA}^{\mathrm{Ser}(\mathrm{CGA})}$ suggests unexpected plasticity in the functional constraints of base pairs, although the variant tRNAs might have minor defects not visible by growth tests.

We provide evidence that Xrn1 purified from yeast can discriminate fine differences in the structure of the acceptor and T-stems of tRNA substrates, since Xrn1 degrades known RTD substrates with near-perfect specificity and relative efficiency in vitro. The physical and genetic data supporting the claim that RTD acts on substrates with weakened acceptor and T-stems are in complete agreement with the recent demonstration that Xrn1 binds its substrate through stacking of the first three 
nucleotides of a single-stranded substrate within the Xrn1 active site (Jinek et al. 2011). The observed complete degradation of tRNA substrates by purified Xrn1 is also consistent with the known processivity of Xrn1 (Stevens 1980; Chang et al. 2011; Jinek et al. 2011), although we note that Xrn1 appears to stall at $\mathrm{Gm}_{18}$ and $\mathrm{Um}_{44}$, the only sites of 2'-O-methylation in our substrate tRNAs (Fig. 7).

It is interesting to consider that Xrn1 activity is balanced so finely as to catalyze degradation of hypomodified or destabilized tRNAs (Chernyakov et al. 2008) and 18S rRNA during nonfunctional rRNA decay (NRD) (Cole et al. 2009), as well as to catalyze $5^{\prime}$ end processing of $5.8 \mathrm{~S}$ RNA, 25S rRNA, and several snoRNAs (Henry et al. 1994; Petfalski et al. 1998; Geerlings et al. 2000; Lee et al. 2003), while avoiding the degradation of mature functioning rRNAs, snoRNAs, and tRNAs. Perhaps Xrn1 activity in RTD is localized to P-bodies, as for 18S rRNA NRD (Cole et al. 2009) and no-go decay (Doma and Parker 2006), or perhaps activity is biochemically limited by accessibility of the $5^{\prime}$ end (Jinek et al. 2011) or by regulatory factors, much as Rail modulates the activity of Rat1 (Xiang et al. 2009). Our results thus may suggest not only that tRNAs have evolved to be stable enough in their acceptor and T-stems to avoid RTD, but, conversely, that Xrn1 and Rat1/Rail have coevolved to avoid activity on tRNAs and other stable cellular RNAs.

\section{Materials and methods}

Yeast strains

The sup61- $\Delta$ [URA3 CEN SUP61] strains were generated by standard methods. The MATa trm44- $\Delta::$ natMX tan1- $\Delta::$ kanMX (JMW119) strain (Supplemental Table S2) and its parent, BY4741 (JMW007), were transformed with a URA3 CEN SUP61 plasmid (JW031), followed by transformation with a sup61- $\Delta:: b l e^{R}$ fragment made by PCR amplification of the pUG66 ble $e^{R}$ cassette (primers in Supplemental Table S3) to generate JMW221 (JMW119 sup61- $::$ ble $^{R}$ [URA3 CEN SUP61]) and JMW223 (BY4741 sup61- $\Delta:: b l e^{R}$ [URA3 CEN SUP61]). Derivatives of JMW221 and JMW223, and plasmids used to make them, are listed in Supplemental Table S4.

tRNA $^{\text {Ser }}$ variants were integrated into JMW221 and JMW223 by transformation of a StuI fragment from JW132-derived plasmids containing a tRNA ${ }^{\text {Ser }}$ variant gene and a MET15 marker flanked by $A D E 2$ sequences, followed by selection on SD-Met medium and screening for $\mathrm{Ade}^{-}$transformants. Then, the URA3 CEN SUP61 plasmid was selected against on SD medium containing $750 \mu \mathrm{g} / \mathrm{mL} 5$-flouroorotic acid. When necessary, a met22- $\Delta:: h p h M X$ cassette was introduced by standard methods after PCR amplification of DNA from the knockout strain.

Construction of plasmids containing $t R N A^{\text {Ser }}$ variants for integration into yeast

To express tRNA ${ }^{\text {Ser }}$ variants, we constructed a tRNA expression cassette that allows for replacement of the tRNA ${ }^{\text {His }}$ sequence with another tRNA sequence, starting with a plasmid harboring a BamH1 fragment containing the tRNA ${ }^{\text {His }(\mathrm{GUG})}$ gene [tH(GUG)G2] and flanking sequences. Using QuikChange (Stratagene), a XhoI site was introduced 22 base pairs $5^{\prime}$ of the +1 site of the mature tRNA sequence, and a BglII site was introduced
21 base pairs $3^{\prime}$ of residue 73 to generate MAB812A. Then, we constructed an integrating vector derived from yIPlac111 by ligation of an $A D E 25^{\prime}$ fragment, the BamHI tRNA expression cassette 3' of the ADE2 fragment, an ADE2 3' fragment 3' of the tRNA cassette, and a MET15 marker ligated between the tRNA cassette and the 3' ADE2 fragment to generate plasmid JW132. Variant tRNA ${ }^{\text {Ser }}$ sequences were then constructed in JW132 using overlapping DNA oligonucleotides (Supplemental Table S5) by treatment with T4 PNK, mixing at $150 \mathrm{mM} \mathrm{NaCl}$, melting for $5 \mathrm{~min}$ at $95^{\circ} \mathrm{C}$, slow cooling to $50^{\circ} \mathrm{C}$, and ligation into JW 132 digested with XhoI and BglII.

\section{Overproduction and purification of $t R N A s$}

tRNA $^{\text {Ser }}$ variants were overexpressed using a URA3 leu2- $d$ multicopy vector (pYEX4T-1) after ligation of the corresponding BamH1 fragment from a JW132-derived plasmid. Strains were grown at $28^{\circ} \mathrm{C}$ in $\mathrm{SD}$-Ura medium, followed by growth in SD -Ura - Leu medium, and 300 OD cell pellets were used to purify tRNA ${ }^{\text {Ser(CGA) }}$ variants from bulk RNA using 5 '-biotinylated oligonucleotides (Supplemental Table S3) as described (Jackman et al. 2003).

\section{Northern blot analysis}

Strains expressing tRNA ${ }^{\text {Ser }}$ variants were grown in YPD medium at $28^{\circ} \mathrm{C}$, thiolutin $(5 \mu \mathrm{g} / \mathrm{mL})$ was added at $\mathrm{OD}_{600}=1.5$, the culture was shifted $10 \mathrm{~min}$ later to $37^{\circ} \mathrm{C}$, and cells $(2 \mathrm{~mL})$ were harvested as indicated, washed, and quick-frozen. Bulk RNA was prepared using hot phenol (Alexandrov et al. 2006), and RNA was separated by $10 \%$ PAGE in $8 \mathrm{M}$ urea and TBE buffer, followed by transfer to Hybond $\mathrm{N}^{+}$membrane, UV cross-linking, and hybridization with $5^{\prime}{ }^{32} \mathrm{P}$-labeled DNA probes (Supplemental Table S3), as described (Alexandrov et al. 2006).

\section{XRN1 cloning, expression, and purification}

XRN1 was cloned into BG2663, a derivative of BG2483, to express $X R N 1$ under $P_{G A L 1}$ control, and fused at its $\mathrm{C}$ terminus to a complex tag containing a protease $3 \mathrm{C}$ site, an HA epitope, His, and the ZZ domain of protein A (Quartley et al. 2009). Plasmids were transformed into strain BCY123 (Macbeth et al. 2005), transformants were grown and induced for expression, and Xrn1 was purified by IgG Sepharose chromatography and 3C protease cleavage, as described (Quartley et al. 2009), followed by dialysis in $20 \mathrm{mM}$ Tris-Cl (pH 7.5), $150 \mathrm{mM} \mathrm{NaCl}, 1 \mathrm{mM}$ DTT, $1 \mathrm{mM}$ $\mathrm{MgCl}_{2}$, and $50 \%$ glycerol, and storage at $-20^{\circ} \mathrm{C}$.

\section{RNase T2 structure probing}

tRNA was 5' end-labeled (Jackman et al. 2003); melted in buffer containing $150 \mathrm{mM} \mathrm{NaCl}$ and $10 \mathrm{mM}$ TrisCl $\left(\mathrm{pH} \mathrm{7.5)}\right.$ at $95^{\circ} \mathrm{C}$; refolded for $10 \mathrm{~min}$ at the reaction temperature with or without $\mathrm{MgCl}_{2}$; incubated for $1 \mathrm{~h}$ in $10-\mu \mathrm{L}$ mixtures containing $150 \mathrm{mM}$ $\mathrm{NaCl}, 10 \mathrm{mM}$ TrisCl $(\mathrm{pH} 7.5), 1 \mathrm{mg} / \mathrm{mL}$ carrier RNA, $\mathrm{MgCl}_{2}$ as indicated, and $1 \mu \mathrm{L}$ of RNase T2 (diluted in $50 \mathrm{mM}$ sodium acetate at $\mathrm{pH} 5.2,40 \%$ glycerol); and resolved on $8 \%$ polyacrylamide gels containing $7 \mathrm{M}$ urea.

\section{Phosphatase assays}

tRNA was $5^{\prime}$ end-labeled (Jackman et al. 2003), refolded, and incubated for $30 \mathrm{~min}$ at $37^{\circ} \mathrm{C}$ in $40-\mu \mathrm{L}$ mixtures containing $150 \mathrm{mM} \mathrm{NaCl}, 25 \mathrm{mM}$ Tris-Cl (pH 8), $1 \mathrm{mM} \mathrm{MgCl} 2,10 \mu \mathrm{g} / \mathrm{mL}$ bovine serum albumin (BSA), and $4 \mu \mathrm{L}$ of CIP (diluted in buffer containing $150 \mathrm{mM} \mathrm{NaCl}, 25 \mathrm{mM}$ Tris-Cl at $\mathrm{pH} 8,100 \mu \mathrm{g} / \mathrm{mL}$ 
BSA). Reactions were stopped by freezing on dry ice and extracted with cold phenol, and $5 \mu \mathrm{L}$ of aqueous layer was applied to a PEI cellulose TLC plate (EMD) and resolved in buffer containing 1.3 M sodium formate, followed by visualization on a Typhoon PhosphorImager (GE Healthcare) and quantification using Imagequant.

\section{Xrn1 and luciferase assays}

RNA was 3' pCp-labeled, refolded, and incubated for $20 \mathrm{~min}$ at $37^{\circ} \mathrm{C}$ in $40-\mu \mathrm{L}$ mixtures containing $150 \mathrm{mM} \mathrm{NaCl}, 25 \mathrm{mM}$ Tris-Cl (pH 8), $2 \mathrm{mM} \mathrm{MgCl} 2,0.5 \mathrm{mM} \mathrm{DTT}, 0.1 \mathrm{mg} / \mathrm{mL} \mathrm{BSA}$, and $4 \mu \mathrm{L}$ of Xrn1 or mock preparation (diluted in Xrn1 storage buffer containing $0.1 \mathrm{mg} / \mathrm{mL}$ BSA). Reactions were stopped by quick-freezing and phenol extraction, and products were resolved by $20 \%$ PAGE in $7 \mathrm{M}$ urea. Luciferase assays were performed essentially as described, using three transformants of each construct and three assays of each transformant (Letzring et al. 2010).

\section{Acknowledgments}

We are grateful to E. Grayhack for valuable discussions, and G. Culver, J. Dewe, and M. Guy for comments on the manuscript. This research was supported by NIH grant GM52347 to E.M.P. J.M.W. was supported by NIH Training Grant in Cellular, Biochemical and Molecular Sciences 5T32 GM068411.

\section{References}

Alexandrov A, Chernyakov I, Gu W, Hiley SL, Hughes TR, Grayhack EJ, Phizicky EM. 2006. Rapid tRNA decay can result from lack of nonessential modifications. Mol Cell 21: 87-96.

Basavappa R, Sigler PB. 1991. The 3 A crystal structure of yeast initiator tRNA: functional implications in initiator/elongator discrimination. EMBO J 10: 3105-3111.

Biou V, Yaremchuk A, Tukalo M, Cusack S. 1994. The 2.9 A crystal structure of T. thermophilus seryl-tRNA synthetase complexed with tRNA(Ser). Science 263: 1404-1410.

Chang JH, Xiang S, Xiang K, Manley JL, Tong L. 2011. Structural and biochemical studies of the $5^{\prime} \rightarrow 3^{\prime}$ exoribonuclease Xrn1. Nat Struct Mol Biol 18: 270-276.

Chernyakov I, Whipple JM, Kotelawala L, Grayhack EJ, Phizicky EM. 2008. Degradation of several hypomodified mature tRNA species in Saccharomyces cerevisiae is mediated by Met 22 and the $5^{\prime}-3^{\prime}$ exonucleases Rat1 and Xrn1. Genes Dev 22: $1369-1380$.

Cole SE, LaRiviere FJ, Merrikh CN, Moore MJ. 2009. A convergence of rRNA and mRNA quality control pathways revealed by mechanistic analysis of nonfunctional rRNA decay. Mol Cell 34: 440-450.

Copela LA, Fernandez CF, Sherrer RL, Wolin SL. 2008. Competition between the Rexl exonuclease and the La protein affects both Trf4p-mediated RNA quality control and pretRNA maturation. RNA 14: 1214-1227.

Dichtl B, Stevens A, Tollervey D. 1997. Lithium toxicity in yeast is due to the inhibition of RNA processing enzymes. EMBO J 16: 7184-7195.

Doma MK, Parker R. 2006. Endonucleolytic cleavage of eukaryotic mRNAs with stalls in translation elongation. Nature 440: $561-564$.

Doma MK, Parker R. 2007. RNA quality control in eukaryotes. Cell 131: 660-668.

Dunin-Horkawicz S, Czerwoniec A, Gajda MJ, Feder M, Grosjean H, Bujnicki JM. 2006. MODOMICS: a database of RNA modification pathways. Nucleic Acids Res 34: D145-D149. doi: $10.1093 /$ nar/gkj084.
Etcheverry T, Salvato M, Guthrie C. 1982. Recessive lethality of yeast strains carrying the SUP61 suppressor results from loss of a transfer RNA with a unique decoding function. $I$ Mol Biol 158: 599-618.

Fahlman RP, Dale T, Uhlenbeck OC. 2004. Uniform binding of aminoacylated transfer RNAs to the ribosomal A and P sites. Mol Cell 16: 799-805.

Fang F, Hoskins J, Butler JS. 2004. 5-Fluorouracil enhances exosome-dependent accumulation of polyadenylated rRNAs. Mol Cell Biol 24: 10766-10776.

Fujii K, Kitabatake M, Sakata T, Miyata A, Ohno M. 2009. A role for ubiquitin in the clearance of nonfunctional rRNAs. Genes Dev 23: 963-974.

Geerlings TH, Vos JC, Raue HA. 2000. The final step in the formation of $25 \mathrm{~S}$ rRNA in Saccharomyces cerevisiae is performed by 5' $\rightarrow$ 3' exonucleases. RNA 6: 1698-1703.

Geslain R, Martin F, Camasses A, Eriani G. 2003. A yeast knockout strain to discriminate between active and inactive tRNA molecules. Nucleic Acids Res 31: 4729-4737.

Giege R, Sissler M, Florentz C. 1998. Universal rules and idiosyncratic features in tRNA identity. Nucleic Acids Res 26: $5017-5035$.

Hall KB, Sampson JR, Uhlenbeck OC, Redfield AG. 1989. Structure of an unmodified tRNA molecule. Biochemistry 28: 5794-5801.

Henry Y, Wood H, Morrissey JP, Petfalski E, Kearsey S, Tollervey D. 1994 . The $5^{\prime}$ end of yeast $5.8 \mathrm{~S}$ rRNA is generated by exonucleases from an upstream cleavage site. $E M B O J$ 13: 2452-2463.

Houseley J, Tollervey D. 2009. The many pathways of RNA degradation. Cell 136: 763-776.

Isken O, Maquat LE. 2007. Quality control of eukaryotic mRNA: safeguarding cells from abnormal mRNA function. Genes Dev 21: 1833-1856.

Jack A, Ladner JE, Klug A. 1976. Crystallographic refinement of yeast phenylalanine transfer RNA at 2-5A resolution. J Mol Biol 108: 619-649.

Jackman JE, Montange RK, Malik HS, Phizicky EM. 2003. Identification of the yeast gene encoding the tRNA $\mathrm{mlG}$ methyltransferase responsible for modification at position 9 . RNA 9: 574-585.

Jinek M, Coyle SM, Doudna JA. 2011. Coupled 5' nucleotide recognition and processivity in xrn1-mediated mRNA decay. Mol Cell 41: 600-608.

Kadaba S, Krueger A, Trice T, Krecic AM, Hinnebusch AG, Anderson J. 2004. Nuclear surveillance and degradation of hypomodified initiator tRNAMet in S. cerevisiae. Genes Dev 18: $1227-1240$.

Kadaba S, Wang X, Anderson JT. 2006. Nuclear RNA surveillance in Saccharomyces cerevisiae: Trf4p-dependent polyadenylation of nascent hypomethylated tRNA and an aberrant form of 5S rRNA. RNA 12: 508-521.

Kawai G, Hashizume T, Miyazawa T, McCloskey JA, Yokoyama S. 1989. Conformational characteristics of 4-acetylcytidine found in tRNA. Nucleic Acids Symp Ser 21: 61-62.

Kotelawala L, Grayhack EJ, Phizicky EM. 2008. Identification of yeast tRNA Um44 2'-O-methyltransferase (Trm44) and demonstration of a Trm 44 role in sustaining levels of specific tRNASer species. RNA 14: 158-169.

Kuai L, Fang F, Butler JS, Sherman F. 2004. Polyadenylation of rRNA in Saccharomyces cerevisiae. Proc Natl Acad Sci 101: 8581-8586.

LaCava J, Houseley J, Saveanu C, Petfalski E, Thompson E, Jacquier A, Tollervey D. 2005. RNA degradation by the exosome is promoted by a nuclear polyadenylation complex. Cell 121: 713-724. 
LaRiviere FJ, Wolfson AD, Uhlenbeck OC. 2001. Uniform binding of aminoacyl-tRNAs to elongation factor $\mathrm{Tu}$ by thermodynamic compensation. Science 294: 165-168.

LaRiviere FJ, Cole SE, Ferullo DJ, Moore MJ. 2006. A late-acting quality control process for mature eukaryotic rRNAs. Mol Cell 24: 619-626.

Ledoux S, Uhlenbeck OC. 2008. Different aa-tRNAs are selected uniformly on the ribosome. Mol Cell 31: 114-123.

Lee CY, Lee A, Chanfreau G. 2003. The roles of endonucleolytic cleavage and exonucleolytic digestion in the $5^{\prime}$-end processing of S. cerevisiae box C/D snoRNAs. RNA 9: 1362-1370.

Letzring DP, Dean KM, Grayhack EJ. 2010. Control of translation efficiency in yeast by codon-anticodon interactions. RNA 16: 2516-2528.

Macbeth MR, Schubert HL, Vandemark AP, Lingam AT, Hill CP, Bass BL. 2005. Inositol hexakisphosphate is bound in the ADAR2 core and required for RNA editing. Science 309: 1534-1539.

McCraith SM, Phizicky EM. 1990. A highly specific phosphatase from Saccharomyces cerevisiae implicated in tRNA splicing. Mol Cell Biol 10: 1049-1055.

Muramatsu T, Nishikawa K, Nemoto F, Kuchino Y, Nishimura S, Miyazawa T, Yokoyama S. 1988. Codon and amino-acid specificities of a transfer RNA are both converted by a single post-transcriptional modification. Nature 336: 179-181.

Musier-Forsyth K, Usman N, Scaringe S, Doudna J, Green R, Schimmel P. 1991. Specificity for aminoacylation of an RNA helix: an unpaired, exocyclic amino group in the minor groove. Science 253: 784-786.

Nobles KN, Yarian CS, Liu G, Guenther RH, Agris PF. 2002. Highly conserved modified nucleosides influence $\mathrm{Mg}^{2+}$. dependent tRNA folding. Nucleic Acids Res 30: 4751-4760.

Olejniczak M, Dale T, Fahlman RP, Uhlenbeck OC. 2005. Idiosyncratic tuning of tRNAs to achieve uniform ribosome binding. Nat Struct Mol Biol 12: 788-793.

Parthasarathy R, Ginell SL, De NC, Chheda GB. 1978. Conformation of N4-acetylcytidine, a modified nucleoside of tRNA, and stereochemistry of codon-anticodon interaction. Biochem Biophys Res Commun 83: 657-663.

Petfalski E, Dandekar T, Henry Y, Tollervey D. 1998. Processing of the precursors to small nucleolar RNAs and rRNAs requires common components. Mol Cell Biol 18: 1181-1189.

Quartley E, Alexandrov A, Mikucki M, Buckner FS, Hol WG, DeTitta GT, Phizicky EM, Grayhack EJ. 2009. Heterologous expression of L. major proteins in S. cerevisiae: a test of solubility, purity, and gene recoding. I Struct Funct Genomics 10: 233-247.

Rasse-Messenguy F, Fink GR. 1973. Temperature-sensitive nonsense suppressors in yeast. Genetics 75: 459-464.

Reuter JS, Mathews DH. 2010. RNAstructure: software for RNA secondary structure prediction and analysis. BMC Bioinformatics 11: 129. doi: 10.1186/1471-2105-11-129.

Salas-Marco J, Bedwell DM. 2005. Discrimination between defects in elongation fidelity and termination efficiency provides mechanistic insights into translational readthrough. J Mol Biol 348: 801-815.

Schneider C, Anderson JT, Tollervey D. 2007. The exosome subunit Rrp44 plays a direct role in RNA substrate recognition. Mol Cell 27: 324-331.

Schrader JM, Chapman SJ, Uhlenbeck OC. 2009. Understanding the sequence specificity of tRNA binding to elongation factor Tu using tRNA mutagenesis. J Mol Biol 386: 1255-1264.

Shelton VM, Sosnick TR, Pan T. 2001. Altering the intermediate in the equilibrium folding of unmodified yeast tRNAPhe with monovalent and divalent cations. Biochemistry 40: 3629-3638.
Stevens A. 1980. Purification and characterization of a Saccharomyces cerevisiae exoribonuclease which yields $5^{\prime}$-mononucleotides by a $5^{\prime}$ leads to $3^{\prime}$ mode of hydrolysis. I Biol Chem 255: 3080-3085.

Vanacova S, Wolf J, Martin G, Blank D, Dettwiler S, Friedlein A, Langen H, Keith G, Keller W. 2005. A new yeast poly(A) polymerase complex involved in RNA quality control. PLOS Biol 3: e189. doi: 10.1371/journal.pbio.00301189.

Westhof E, Dumas P, Moras D, Romby P. 1985. Crystallographic refinement of yeast aspartic acid transfer RNA. I Mol Biol 184: $119-145$.

Xiang S, Cooper-Morgan A, Jiao X, Kiledjian M, Manley JL, Tong L. 2009. Structure and function of the $5^{\prime} \rightarrow 3^{\prime}$ exoribonuclease Rat 1 and its activating partner Rail. Nature 458: 784788.

Yue D, Kintanar A, Horowitz J. 1994. Nucleoside modifications stabilize $\mathrm{Mg}^{2+}$ binding in Escherichia coli tRNA(Val): an imino proton NMR investigation. Biochemistry 33: 89058911. 


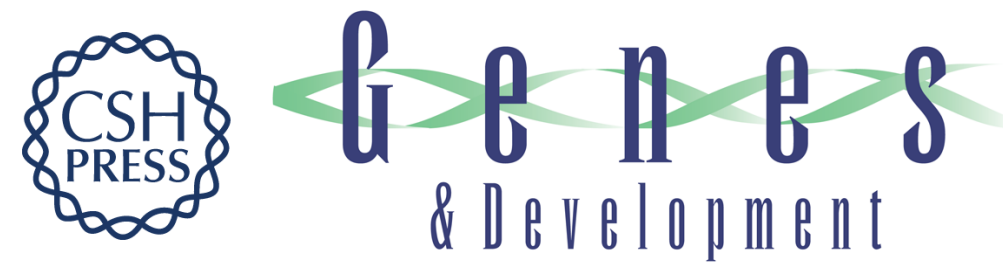

\section{The yeast rapid tRNA decay pathway primarily monitors the structural integrity of the acceptor and T-stems of mature tRNA}

Joseph M. Whipple, Elizabeth A. Lane, Irina Chernyakov, et al.

Genes Dev. 2011, 25:

Access the most recent version at doi:10.1101/gad.2050711

Supplemental http://genesdev.cshlp.org/content/suppl/2011/05/31/25.11.1173.DC1
Material

References This article cites 56 articles, 21 of which can be accessed free at:

http://genesdev.cshlp.org/content/25/11/1173.full.html\#ref-list-1

License

Email Alerting

Receive free email alerts when new articles cite this article - sign up in the box at the top

Service

right corner of the article or click here.

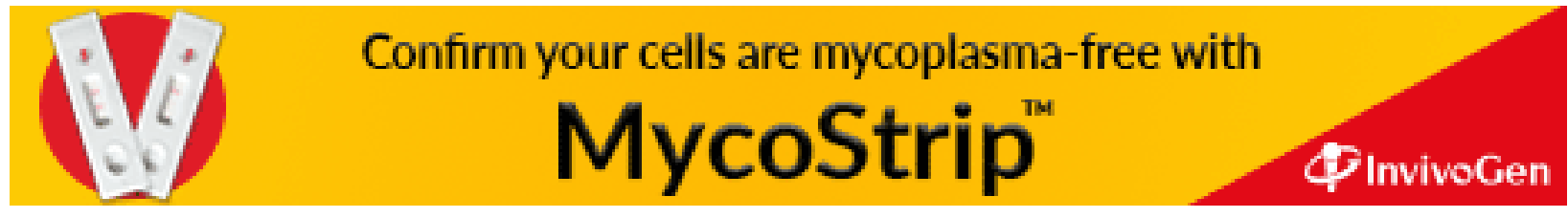

